\title{
Normal coordinate analyses of molecules with the amide group
}

\author{
J. JAKES and S. KRIMM* \\ Harrison M. Randall Laboratory of Physics, University of Michigan, Ann Arbor \\ Michigan
}

(Received 30 December 1969)

\begin{abstract}
Normal coordinate analyoes have been performed on molecules with the amide group using force constants transferred from $\mathrm{N}$-methylacetamides and polyamides. The molecules involved were hexamethylenedipropionamide, $\mathrm{N}, \mathrm{N}^{\prime}$-dihexyladipamide, $\mathrm{N}, \mathrm{N}^{\prime}$-dihexylsebacamide, some $\mathrm{N}$-alkylamides, and some $\mathrm{C}$-deuterated derivatives of nylon 66 . In some molecules the dependence of frequencies on torsion angles about $\mathrm{C}-\mathrm{C}=\mathrm{O})$ or $\mathrm{N}-\mathrm{C}\left(=\mathrm{H}_{2}\right)$ was studied. Dispersion curves were obtained for nylon 6 and nylon 66. The agreement between observed and calculated frequencies is good in most cases, and a complete or nearly complete assignment of infrared frequencies has been established.
\end{abstract}

\section{INTRODUCTION}

In the preceding paper [1], a force field for the amide group was derived. The goal of this paper is to apply this force field to other molecules with the amide group which were not part of the previous refinement. For these we have selected $\mathrm{N}$-alkylamides and diamides, whose infrared spectra were measured by K KRsLFR [2], two C-deuterated nylon 66 with data from Himpmass [3], and the $\gamma$ form of nylon 6. In some moleoules the dependence of frequencies on torsion angles was studied, and dispersion curves for nylon 6 and 66 were obtained. The agreement between calculated and experimental frequencies is generally good, although some features in the spectra still remained unexplained.

\section{Strocture of Molecules}

While the structure of nylons has been thoroughly studied and well established by X-ray diffraction, for example by BuNN et al. [4], KINOSHTA [5], and BraDBURY and EцLіот [6], in the other molecules with the amide group studied here we were able to find the complete $X$-ray structure in the literature only for hexamethylenedipropionamide [7]. This determination shows the backbone to be nearly planar with only a very small deviation from planarity. In the other molecules we must rely on the infrared spectra for a structure determination. In view of the presence of a strong $1420^{\prime} \mathrm{cm}^{-1}$ band in the spectra of $\mathrm{N}, \mathrm{N}^{\prime}$-dihexyladipamide and $\mathrm{N}, \mathrm{N}^{\prime}$-dihexylsebacamide, we assumed their structures to be planar or nearly planar like that of hexamethylenedipropionamide. We do not know anything about the structures of $\mathrm{N}$-ethylacetamide,

* Permanent address: Institute of Macromolecular Chemistry, Czechoslovak Acedemy of Sciences, Prague, Czechoslovakia.

[1] J. JAKRŠ and S. KRTMM, Spectrochim. Acta 27A, 19 (1971).

[2] H. B. Krassuer, Ph.D. Thesis, University of Michigan (1952).

[3] G. Hirdmunans and H. ZAFn, Makromol. Chem. 6Q, 123 (1963).

[4] D. R. Holsme, C. W. Buns and D. J. Sucrit, J. Polymer Sci. 17, 159 (1955).

[6] Y. Krnosimis, Maloromol. Chem. 33, 1 (1959); 38, 21 (1959).

[6] E. M. Bradbury, L. Brown, A. Erujotr and D. A. D. Parry, Polymer 6, 465 (1965).

[7] L. H. Jinster, S. Krnm, R. G. Parrish and D. L. Wood, Acta Cryst. 10, 628 (1957). 
$\mathrm{N}$-propylacetamide, and N-butylacetamide. Therefore we performed frequency calculations for these molecules as a function of the torsion angle about the $\mathrm{NH}-$ $\mathrm{CH}_{2}$ bond. This dependence turned out to be very small in the region above $700 \mathrm{~cm}^{-1}$, where the only data are available, and therefore the calculations were of little help for structure determinations. Some hints showing the probability of the presence of more than one conformation were found in the region below $1000 \mathrm{~cm}^{-1}$. In the $\mathrm{N}$-alkylpropionamides, the absence of a $1420 \mathrm{~cm}^{-1}$ band shows that the torsion angle about the $\mathrm{CH}_{2}-\mathrm{CO}$ bond should differ from the trans angle. We calculated the complete dependence of frequencies on this angle for $\mathrm{N}$-methylpropionamide. For $\mathrm{N}$-ethylpropionamide, $\mathrm{N}$-propylpropionamide and $\mathrm{N}$-butylpropionamide, we used the values $\left(0^{\circ}, 0^{\circ}\right),\left(45^{\circ},-45^{\circ}\right),\left(60^{\circ},-60^{\circ}\right),\left(45^{\circ}, 45^{\circ}\right)$ and $\left(60^{\circ}, 60^{\circ}\right)$ for the torsion angles about the $\mathrm{CH}_{2}-\mathrm{CO}$ and $\mathrm{NH}-\mathrm{CH}_{2}$ bonds. The first pair of angles corresponds to the planar form and the next two to a structure similar to that of the $\gamma$-form of nylon 6 (the actual torsion angle should lie between $45^{\circ}$ and $60^{\circ}$ ). The last two were added in order to learn something about the interaction between the two torsions. The same values of the torsion angles, omitting the last two, were used in $\mathrm{N}$-nonylcapramide and in the $\gamma$-form of nylon 6.

The rotations about the $\mathrm{CO}-\mathrm{CH}_{2}$ and $\mathrm{NH}-\mathrm{CH}_{2}$ bonds introduces the problem of the dependence of cross force constants between the $\mathrm{A}-\mathrm{B}-\mathrm{C}$ and $\mathrm{B}-\mathrm{C}-\mathrm{D}$ angle coordinates on the torsion angle about the $B-C$ bond. We felt that it was not worth while assigning an independent value of this cross term to each torsional angle, and instead we used for this term an interpolation formula, $f_{i j}=a+b \cos \phi$. Instead of introducing the constants $a$ and $b$, we introduced the values of $f_{i j}$ for $60^{\circ}$ and $180^{\circ}$ (if the conformation in the planar form was trans or gauche) or for $0^{\circ}$ and $120^{\circ}$ (in the case of cis or skew conformations). For the interaction between the $\mathrm{X}-\mathrm{C}-\mathrm{C}$ angle and the $\mathrm{CO}$ out-of-plane bend we used the formula $c \sin \phi$, where $\phi$ is the $\mathrm{X}-\mathrm{C}-\mathrm{C}-\mathrm{N}$ dihedral angle; a similar relation was used for the interaction between the $\mathrm{X}-\mathrm{C}-\mathrm{N}$, angle and the NH out-of-plane bend. This introduces a total of 10 new force constants five for each rotated bond. Four of these were determined from $\mathrm{N}$-methylacetamide (e.g. cis $\mathrm{HCC}$ with $\mathrm{CCO}$ ). We do not have any information about the values of the remaining six constants, and these were assigned zero values. This leads to some uncertainty in the calculated frequencies for nonplanar forms, and probably some discrepancies between calculated and experimental frequencies may be explained in such terms.

\section{Results and Discossion}

\section{$\gamma$-form of nylon 6}

The $\gamma$-form of nylon 6 may be obtained from the planar form by rotation about the $\mathrm{CO}-\mathrm{CH}_{2}$ and $\mathrm{NH}-\mathrm{CH}_{2}$ bonds by the same angle but in opposite directions [5, 6]. The value of the angle is a bit below $60^{\circ}$, and we chose for the calculation the values $45^{\circ}$ and $60^{\circ}$ in order to see how sensitive the calculated frequencies are to small changes of this angle. The polymer chain is generated from the repeating unit by the operation $C_{2 s}$, the unit cell contains two repeating units, and the factor group of the chain is $C_{2}$. Therefore, each mode of the monomer unit is split into two infrared active modes, one of species $A$, polarized parallel to the chain axis, and the other of 
Table 1. Experimental and calculated frequencies of $\gamma$-nylon 6, normal and $N$-deuterated, as a function of $\mathrm{CH}_{2}-\mathrm{CO}$ and $\mathrm{NH}-\mathrm{CH}_{2}$ torsion angles

\begin{tabular}{|c|c|c|c|c|c|}
\hline \multirow[b]{3}{*}{ Exp. $[8,9]$} & \multicolumn{4}{|c|}{$\gamma$-nylon 6} & \multirow[b]{3}{*}{ Assignment } \\
\hline & \multicolumn{2}{|c|}{$\phi=45^{\circ}$} & \multicolumn{2}{|c|}{$\phi=60^{\circ}$} & \\
\hline & $A^{\top}$ & $\boldsymbol{B}$ & $A$ & $\boldsymbol{B}$ & \\
\hline 1643 & 1653 & 1653 & 1657 & 1657 & Amide I \\
\hline \multirow{2}{*}{1567} & 1655 & 1556 & 1555 & 1555 & Amide II \\
\hline & 1477 & 1478 & 1477 & 1477 & $B_{5}$ \\
\hline 1463 & 1473 & 1474 & 1473 & 1473 & $B$ \\
\hline & 1461 & 1459 & 1460 & 1459 & $B$ \\
\hline \multirow[t]{3}{*}{1439} & 1441 & 1442 & 1439 & 1440 & $B$ \\
\hline & 1420 & 1420 & 1420 & 1420 & $B_{1}$ \\
\hline & 1382 & 1385 & 1383 & 1384 & $\bar{w}_{5}^{2}$ \\
\hline \multirow[t]{3}{*}{1369} & 1369 & 1374 & 1370 & 1375 & $W_{4}$ \\
\hline & 1366 & 1348 & 1364 & 1348 & Amide III \\
\hline & 1307 & 1302 & 1308 & 1302 & $T_{2}$ \\
\hline \multirow[t]{2}{*}{1300} & 1306 & 1305 & 1305 & 1304 & $T_{1}$ \\
\hline & 1296 & 1320 & 1296 & 1321 & $W_{8}$ \\
\hline 1280 & 1280 & 1279 & 1271 & 1278 & $T_{\mathrm{8}}$ \\
\hline 1266 & 1271 & 1251 & 1280 & 1253 & $w_{z}$ \\
\hline 1235 & 1234 & 1235 & 1231 & 1235 & $T_{t}$ \\
\hline 1216 & 1204 & 1217 & 1205 & 1218 & $W_{1}$ \\
\hline 1170 & 1180 & 1176 & 1186 & 1176 & $T_{s}$ \\
\hline 1120 & 1134 & 1126 & 1136 & 1132 & $s_{1}^{0}$ \\
\hline \multirow{4}{*}{1078} & $\{1088$ & 1081 & 1082 & 1078 & $\boldsymbol{R}_{3}$ \\
\hline & $\{1071$ & 1086 & 1067 & 1082 & $S_{2}$ \\
\hline & 1064 & 1084 & 1084 & 1064 & $S_{s}$ \\
\hline & 1046 & 1025 & 1046 & 1025 & $S_{4}$ \\
\hline 1000 & 1002 & 1013 & 998 & 1007 & $\tilde{S}_{3}$ \\
\hline 976 & 961 & 037 & 963 & 924 & $R_{4}$ \\
\hline \multirow{2}{*}{914} & 925 & 969 & 022 & 971 & $\mathrm{CH}_{3}-\mathrm{CO}$ stretch \\
\hline & 838 & 840 & 830 & 839 & $\boldsymbol{B}_{3}$ \\
\hline \multirow[t]{2}{*}{777} & 765 & 776 & 764 & 782 & $\boldsymbol{B}_{2}$ \\
\hline & 744 & 735 & 752 & 738 & Amide IV \\
\hline 730 & 722 & 725 & 721 & 724 & $R_{1}$ \\
\hline 711 & 695 & 693 & 692 & 691 & Amide V \\
\hline 623 & 619 & 605 & 630 & 617 & Amide VI \\
\hline 519 & 516 & 511 & 514 & 508) & \multirow{12}{*}{$\begin{array}{l}\text { Skeletal bend } \\
\text { and toraion }\end{array}$} \\
\hline \multirow[t]{11}{*}{439} & 449 & 434 & 446 & 438 & \\
\hline & 377 & 336 & 384 & 338 & \\
\hline & 307 & 284 & 309 & 296 & \\
\hline & 248 & 259 & 268 & 269 & \\
\hline & 133 & 194 & 137 & 198 & \\
\hline & 123 & 154 & 123 & 148 & \\
\hline & 89 & 124 & 94 & 123 & \\
\hline & 66 & 100 & 71 & 101 & \\
\hline & 46 & 65 & 45 & 62 & \\
\hline & 38 & 61 & 38 & 60 & \\
\hline & 21 & 39 & 21 & 38) & \\
\hline \multirow[b]{3}{*}{ Exp. [9] } & \multicolumn{4}{|c|}{ N-deutersted $\gamma$-nylon 6} & \\
\hline & \multicolumn{2}{|c|}{$\phi=45^{\circ}$} & & & \\
\hline & $A$ & $B$ & $A$ & $B$ & Assignment \\
\hline 1636 & 1639 & 1639 & 1643 & 1643 & Amide I \\
\hline 1476 & 1488 & 1490 & 1489 & 1491 & Amide II \\
\hline & 1476 & 1476 & 1475 & 1475 & $B_{5}$ \\
\hline 1467 & 1471 & 1470 & 1472 & 1469 & $\bar{B}_{A}$ \\
\hline & 1458 & 1489 & 1456 & 1459 & $R_{3}$ \\
\hline 1436 & 1440 & 1440 & 1438 & 1438 & $B_{2}$ \\
\hline & 1420 & 1420 & 1420 & 1420 & $B_{1}$ \\
\hline 1373 & 1376 & 1376 & 1376 & 1376 & $W_{s}^{2}$ \\
\hline 1373 & $\{1368$ & 1372 & 1369 & 1372 & $w_{4}$ \\
\hline
\end{tabular}


Table 1 (cont.)

\begin{tabular}{|c|c|c|c|c|c|}
\hline \multirow[b]{3}{*}{ Exp. [0] } & \multicolumn{4}{|c|}{$\begin{array}{l}\text { N-deuterated } \gamma \text {-nylon } 6 \text { (cont.) } \\
\text { Calo. }\end{array}$} & \multirow[b]{3}{*}{ Assignment } \\
\hline & \multicolumn{2}{|c|}{$\phi=45^{\circ}$} & \multicolumn{2}{|c|}{$\phi=60^{\circ}$} & \\
\hline & $A^{\top}$ & $B$ & $A$ & $\boldsymbol{B}$ & \\
\hline & 1339 & 1335 & 1338 & 1336 & $W_{*}$ \\
\hline 1302 & $\left\{\begin{array}{l}1308 \\
1303\end{array}\right.$ & 1305 & 1305 & 1308 & $T_{1}$ \\
\hline & 1282 & $\begin{array}{l}1302 \\
1283\end{array}$ & $\begin{array}{l}1302 \\
1284\end{array}$ & $\begin{array}{l}1302 \\
1282\end{array}$ & $T_{9}$ \\
\hline 1284 & $\{1279$ & 1278 & 1278 & 1274 & $w_{*}^{*}$ \\
\hline 1237 & 1233 & 1239 & 1230 & 1241 & $x_{4}$ \\
\hline 1220 & 1218 & 1216 & 1217 & 1217 & $w_{1}$ \\
\hline 1171 & 1184 & 1176 & 1193 & 1177 & $T_{3}^{2}$ \\
\hline 1133 & 1133 & 1140 & 1135 & 1143 & $s_{1}^{b}$ \\
\hline 1079 & $\{1091$ & 1087 & 1085 & 1083 & $\hat{s}_{3}$ \\
\hline 1078 & 1080 & 1081 & 1073 & 1076 & $\boldsymbol{R}_{\mathbf{s}}$ \\
\hline & 1064 & 1064 & 1064 & 1064 & $S_{5}$ \\
\hline & 1053 & 1033 & 1053 & 1032 & $s$ \\
\hline 1000 & 897 & 1012 & 895 & 1006 & $S_{8}$ \\
\hline 974 & 884 & 992 & 983 & 993 & Amide III \\
\hline & 956 & 950 & 957 & 961 & $\boldsymbol{R}_{\boldsymbol{q}}$ \\
\hline 913 & 920 & 929 & 917 & 917 & $\begin{array}{r}\mathrm{CH}_{\mathrm{a}}-\mathrm{CO} \\
\text { gtroteh }\end{array}$ \\
\hline 831 & 835 & 836 & 828 & 837 & $\boldsymbol{R}_{3}$ \\
\hline 771 & 750 & 767 & 759 & 769 & $R_{2}$ \\
\hline & 734 & 727 & 738 & 730 & Amide IV \\
\hline 733 & 721 & 723 & 720 & 723 & $\boldsymbol{B}_{1}$ \\
\hline 633 & 639 & & 648 & & Amide VI \\
\hline 611 & & 624 & & 633 & \\
\hline 527 & 522 & 512 & 624 & 813 & Amide V \\
\hline & 493 & 498 & 488 & $496)$ & \\
\hline 441 & 445 & 433 & 444 & 437 & \\
\hline & 375 & 336 & 383 & 338 & \\
\hline & 306 & 281 & 309 & 203 & \\
\hline & 248 & 257 & 267 & 266 & \\
\hline & 133 & 193 & 136 & 198 & Skeletal bend \\
\hline & 123 & 153 & 123 & 147 & and torsion \\
\hline & 88 & 124 & 98 & 123 & \\
\hline & 65 & 100 & 71 & 101 & \\
\hline & 46 & 65 & 45 & 62 & \\
\hline & 38 & 60 & 38 & 60 & \\
\hline & 21 & 38 & 21 & 37) & \\
\hline
\end{tabular}

species $B$, polarized perpendicular to the chain axis. The calculated and experimental $[8,9]$ frequencies of ordinary and $N$-deuterated nylon 6 are listed in Table 1 together with assignments made on the basis of eigenvectors. These assignments may become ambiguous for individual modes which are interacting strongly, but in any case each frequency contains a large contribution from the mode to which it was assigned. The symbols $B, W, T, R$ and $S$ refer to the $\mathrm{CH}_{2}$ bending, wagging, twisting, rocking and $\mathrm{C}-\mathrm{C}$ stretching modes in the polymethylene chain, respectively, and each bears the sequence index of the chain progression. From this table the frequency of the amide $V$ band is seen to be almost $20 \mathrm{~cm}^{-1}$ off its calculated value. This frequency is sensitive to some of the force constants which were neglected (see above), and moreover it may be influenced by interaction with the amide IV mode, whose position in polyamides is uncertain. The calculated frequency at 1420 $\mathrm{cm}^{-1}$ is seen to be quite insensitive to the rotation angle. This is in contrast with its absence or shift to $1440 \mathrm{~cm}^{-1}$ in the spectrum of the $\gamma$-form. Since another frequency

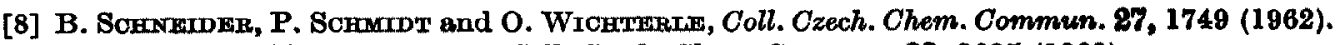

[9] P. Scrurror and B. Sornerdier, Coll. Czech. Chem. Commun. 28, 2685 (1963). 
is calculated at $1440 \mathrm{~cm}^{-1}$, we cannot decide if this frequency is greatly reduced in intensity and hidden on the side of the $1440 \mathrm{~cm}^{-1}$ band, or is simply shifted to 1440 $\mathrm{cm}^{-1}$. The fact that the corresponding eigenvector is also quite insensitive to the rotation angle does not seem to support the hypothesis of great reduction of intensity after rotation. All other features of the spectra except the two mentioned above are explained quite well by the calculation, and the calculated and experimental frequencies are very close.

To follow the dependence of frequencies on rotation angle more closely, we calculated the complete dependence of the frequencies of ordinary (nondeuterated) nylon 6 on the angles about the $\mathrm{CO}-\mathrm{CH}_{2}$ and $\mathrm{NH}-\mathrm{CH}_{2}$ bonds. We let these angles change from the standard all-trans values by the same amount in opposite directions in the interval from $0^{\circ}$ to $180^{\circ}$ in steps of $15^{\circ}$, and also in the same direction in steps of $30^{\circ}$ (a change of sign in both angles does not affect the frequencies) to get some information about interaction of these two rotations. With these rotation angles, frequencies were calculated for phase differences of $0^{\circ}$ and $180^{\circ}$ in the polymer (note that for rotation in the same direction the $180^{\circ}$ modes are not unit cell modes). The plots of the dependence of each frequency on the rotation angles are shown in Fig. 1.

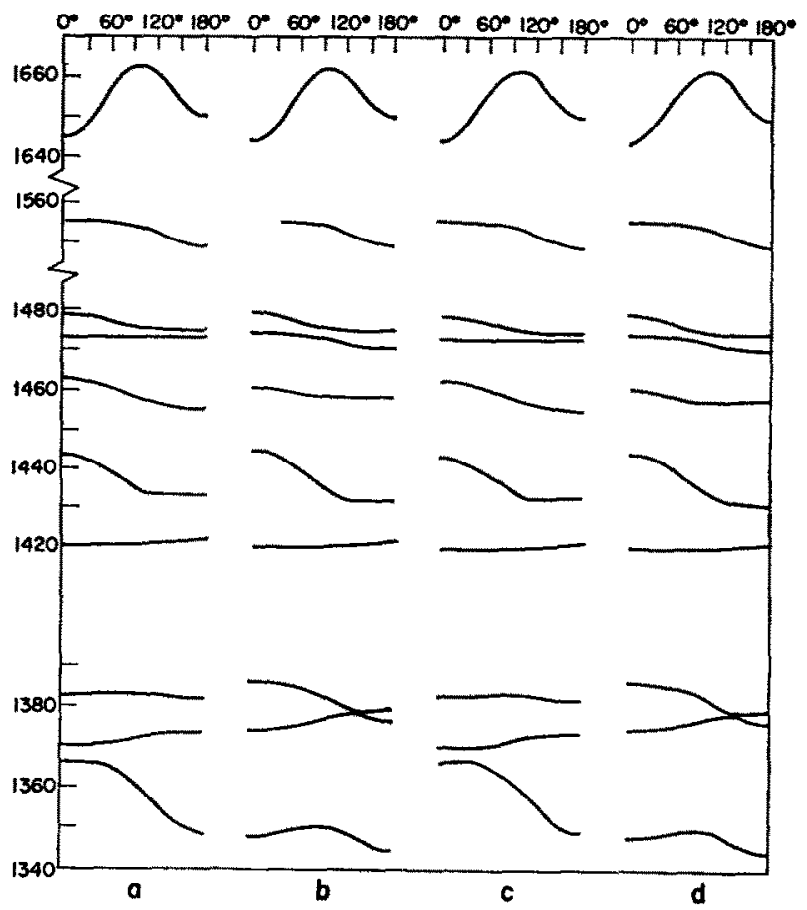

Fig. 1(8)

Fig. 1. The dependence of the frequencies of nylon 6 on the torsion angles around the $\mathrm{CO}-\mathrm{CH}_{2}$ and $\mathrm{CH}_{2}-\mathrm{NH}$ bonds. Both torsion angles are changed by the same value, either in the seme direction, or in opposite directions. The dependence is shown for phase differences between sdjacent monomer units of $\phi=0^{\circ}$ and $180^{\circ}$. (B) rotation in opposite direction, $\phi=0^{\circ}$; (b) rotation in opposite direction, $\phi=180^{\circ}$; (c) rotation in the same direction, $\phi=0^{\circ}$; (d) rotation in the same direction, $\phi=180^{\circ}$. 


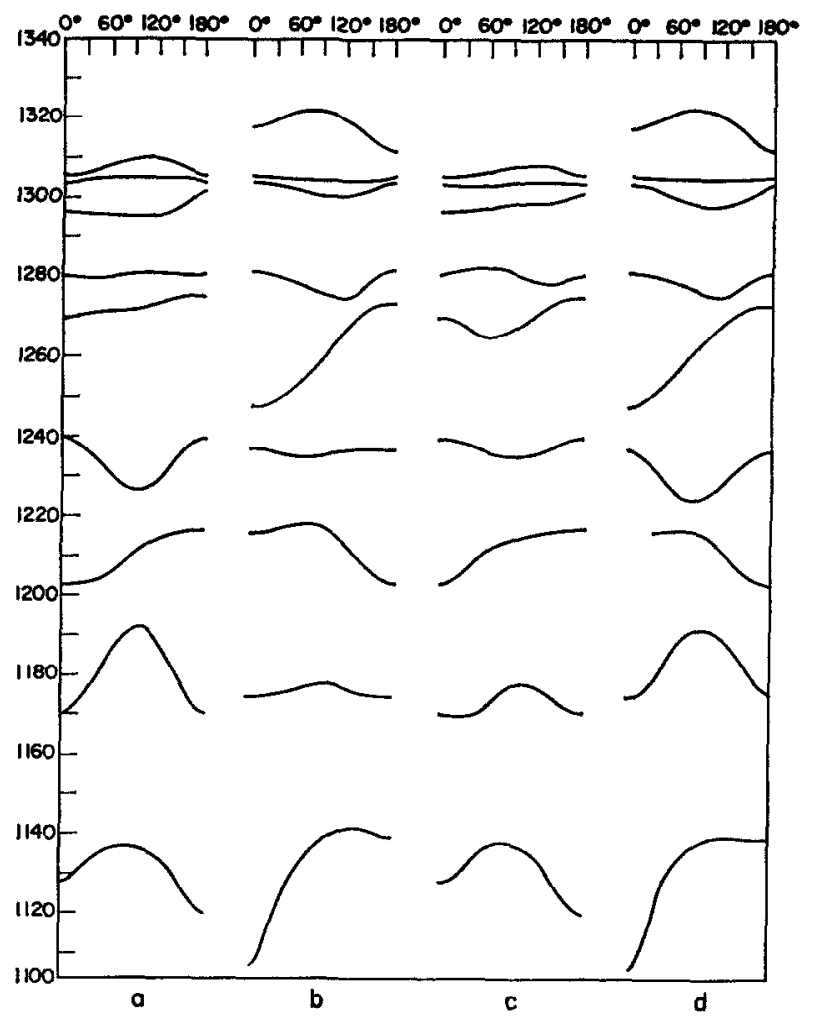

Fig. 1(b)

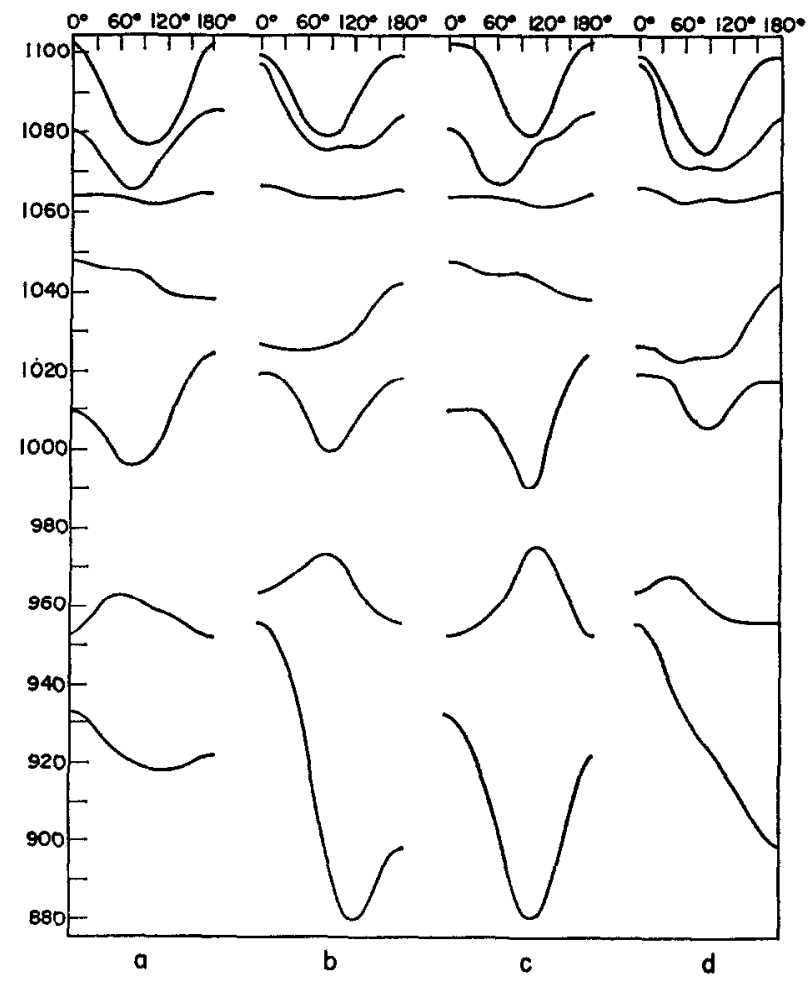

Fig. 1(c) 


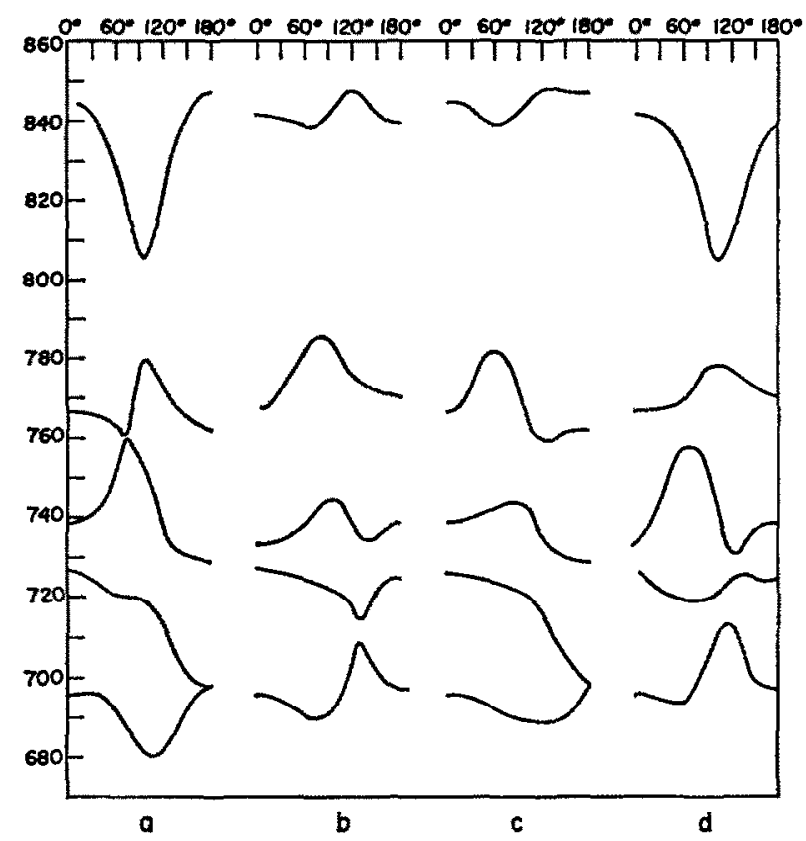

Fig. 1 (d)

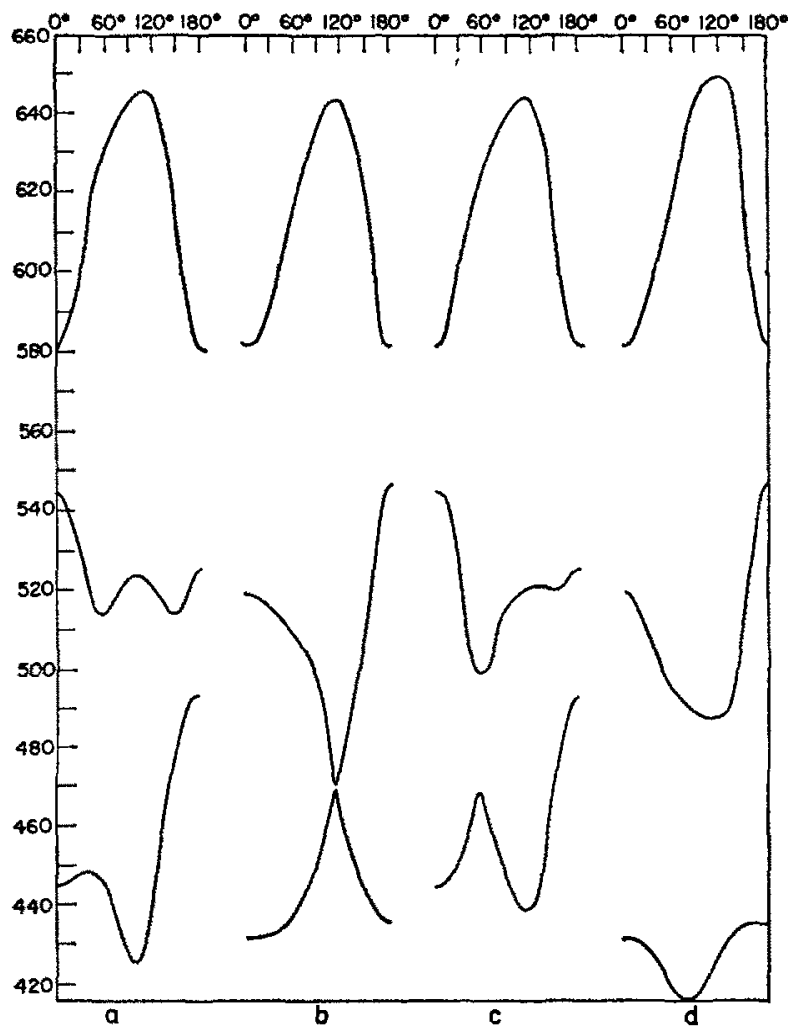

Fig. $1(\mathrm{e})$ 


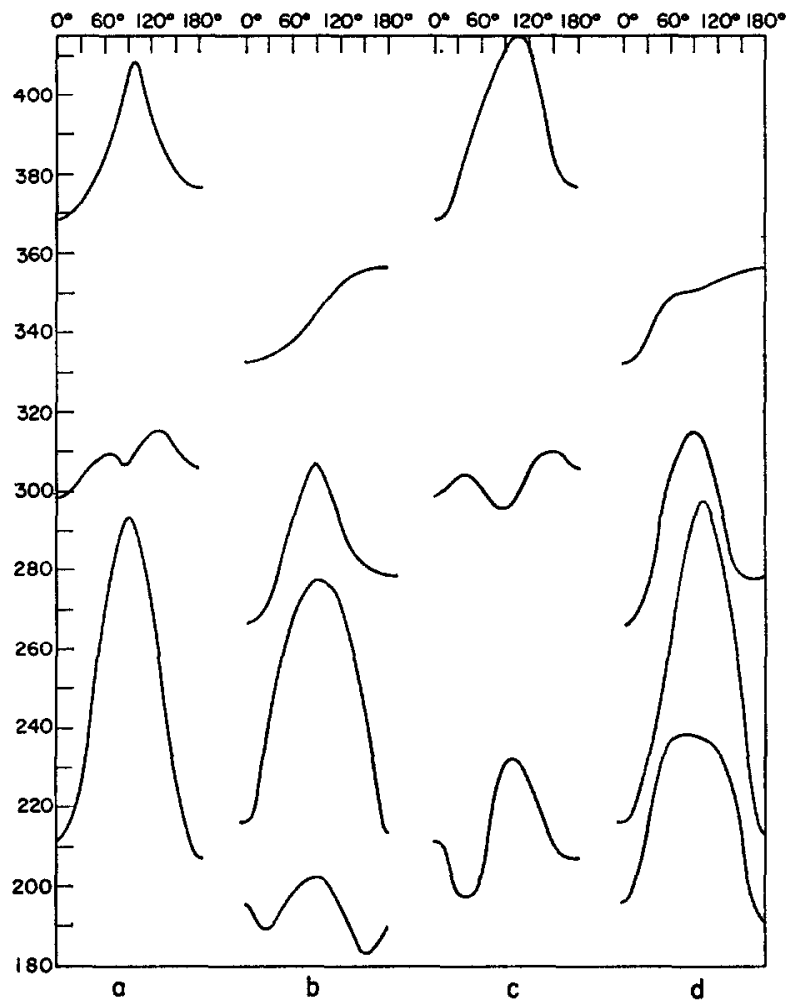

Fig. 1 (f)

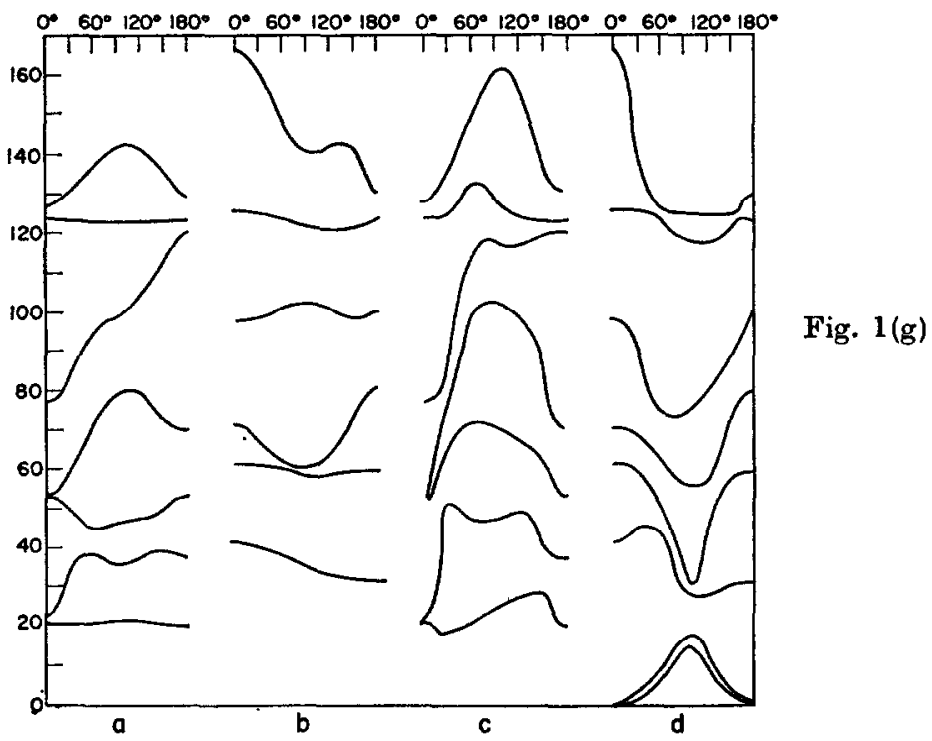




\section{Diamides}

Spectra of three of the diamides, namely hexamethylenedipropionamide, $N, N^{\prime}$ dihexyladipamide, and $N, N^{\prime}$-dihexylsebacamide, were measured by KessLEr [2]. Our calculated infrared active frequencies for these molecules are compared with the experimental values in Table 2. For the first molecule the structure is well established by $\mathrm{X}$-ray analysis [7]. For the last two, no such structure analysis is available; however, polarized spectra of long, thin single crystals have been obtained [2]. An examination of the dichroism of bands in these spectra shows that out-of-plane modes $\left(A_{u}\right)$ are predominantly perpendicular to the plane of cleavage (which is parallel to the long dimension of the crystal and perpendicular to the surface planes which define the thin dimension), while in-plane modes can be parallel or perpendicular to this plane.

Table 2. Experimental and calculated frequencies of some diamides

\begin{tabular}{|c|c|c|c|c|c|c|c|}
\hline \multicolumn{4}{|c|}{ Hexamethylenedipropionamide } & \multicolumn{4}{|c|}{$\mathrm{N}, \mathrm{N}^{\prime}$-dihexyladipamide } \\
\hline Exp. [2] & $B_{w}$ & $A_{*}$ & Assignment & Exp.[2] & $B_{*}$ & $A_{*}$ & Aseignment \\
\hline 1623 & 1644 & & Amide I & $1634 \mid\}$ & 1645 & & Amide I \\
\hline 1634 & $\begin{array}{l}1556 \\
1478\end{array}$ & & Amide II & $1610 \| S$ & & & Amide II \\
\hline lens & 1474 & & $B_{a}$ & $1530 \|$ & 1656 & & \\
\hline 1464 & 1461 & 1458 & $\mathrm{CH}_{3}$ as bend & 1477 & 1479 & & $B_{\varepsilon}(\mathrm{NH})$ \\
\hline 1443 & 1446 & & $B_{2}$ & & 1474 & & $B_{a}(\mathrm{NH})$ \\
\hline 1418 & 1427 & & $\mathrm{CH}_{2}(\mathrm{CO})$ bend & 1466 & 1472 & & $B_{4}(\mathrm{CO})$ \\
\hline & $\begin{array}{l}1374 \\
1371\end{array}$ & & CH, $W_{5 m}$ bend & & $\begin{array}{r}11471 \\
1460\end{array}$ & 1458 & $\begin{aligned} B_{3}(\mathrm{NH}) \\
\mathrm{CH}, \mathrm{sg} \text { bend }\end{aligned}$ \\
\hline 1382 & 1362 & & Amide III & 1449 & 1452 & & $B_{9}(\mathrm{NH})$ \\
\hline & 1332 & & $W_{2}$ & $144 y$ & 1442 & & $B_{2}(\mathrm{NH})$ \\
\hline & & 1305 & & $1414 \|$ & 1422 & & $B_{z}(C)$ \\
\hline 1272 & & 1269 & $\mathrm{CH}_{2}(\mathrm{CO})$ twist & 1385 & 1381 & & $\bar{W}_{5}(\mathrm{NH})$ \\
\hline 1269 & & 1260 & $T_{4}$ & 1370 & 1378 & & Amide III \\
\hline 1244 & 1261 & & $\mathrm{CH}_{2}(\mathrm{CO}) \mathrm{wag}$ & 1370 & $\left\{\begin{array}{l}1373 \\
\end{array}\right.$ & & $\mathrm{CH}_{3} \mathrm{sym}$ bend \\
\hline 1215 & 1217 & & $W_{1}$ & & 1366 & & $W_{s}(\mathrm{NH})$ \\
\hline 1176 & & 1178 & $T_{a}$ & $1340 \|$ & 1343 & & $W_{3}(\mathrm{NH})$ \\
\hline 1103 & 1111 & & $S_{2}$ & & & $(1305$ & $T_{1}(\mathrm{NH})$ \\
\hline & & 1073 & $R_{2}(\mathrm{CO})$ & 1302 & & 1304 & $T_{3}(\mathrm{NH})$ \\
\hline 1064 & 1067 & & $S_{a}$ & & & 1302 & $T_{q}(\mathrm{CO})$ \\
\hline 1047 & 1058 & & $\mathrm{CH}_{8}$ rock & 1284 & 1296 & & $W_{2}(\mathrm{NH})$ \\
\hline 1029 & 1038 & & $s_{4}$ & 1287 & & 1285 & $T_{3}(\mathrm{NH})$ \\
\hline 896 & & 903 & & 12711 & 1278 & & $w_{3}(\mathrm{CO})$ \\
\hline 984 & 990 & & $\mathrm{CH}_{3}-{ }_{\mathrm{C}}^{\mathrm{C}} \mathrm{H}_{2}$ stretoh & 1263 & & 1248 & $T_{4}(\mathrm{NH})$ \\
\hline 898 & 897 & & $\mathrm{CH}_{2}-\mathrm{CO}$ stretoh & 1233! & 1231 & & $W_{1}(\mathrm{NH})$ \\
\hline 811 & & 808 & $R_{1}(\mathrm{CO})$ & $1200 \perp$ & & 1201 & $T_{s}(\mathrm{NH})$ \\
\hline 796 & & 797 & $\boldsymbol{R}_{\mathbf{3}}$ & $1183 \|$ & 1200 & & $W_{1}(\mathrm{CO})$ \\
\hline 735 & & 721 & & 1156 & & 1158 & $R(\mathrm{NH})$ \\
\hline 687 & & 697 & Amide V & 1138 & 1134 & & $S_{1}(\mathrm{NH})$ \\
\hline & 683 & & Amido IV & 1133 & & 1144 & $T_{4}(\mathrm{CO})$ \\
\hline & & 580 & Amide VI & 1086 & 1102 & & $S_{2}(\mathrm{NH})$ \\
\hline & 536 & & & $1005 \|$ & 1087 & & $S_{\mathrm{a}}(\mathrm{NH})$ \\
\hline & 391 & & Skelatal bend & 1052l & 1056 & & $S_{5}(\mathrm{NH})$ \\
\hline & $\mathbf{3 2 0}$ & & Skeletal bend & $1052 \|$ & 1081 & & $s_{2}(\mathrm{NH})$ \\
\hline & 275 & & & $1028 \perp$ & 1031 & & $S_{3}(\mathrm{CO})$ \\
\hline & & & Amide VII & & 999 & & $S_{4}(\mathrm{NH})$ \\
\hline & & 187 & $\mathrm{CH}_{\mathrm{a}}$ torsion & 9911 & & 996 & $R_{\mathrm{B}}(\mathrm{NH})$ \\
\hline & 156 & 128 & & $\begin{array}{l}936 \| \\
907\end{array}$ & 944 & 904 & $\begin{array}{c}\text { C-CO stretch } \\
R_{3}(\mathrm{CO})\end{array}$ \\
\hline & & 84 & Skeletal bend & 890 & $\left\{\begin{array}{l}891 \\
\end{array}\right.$ & 890 & $\mathrm{CH}_{2}$ rook \\
\hline & 29 & & and toraion & $800 \perp$ & & 798 & $\boldsymbol{R}_{\mathbf{8}}(\mathbf{N H})$ \\
\hline & & 28 & & $748 \bar{I}$ & 748 & & Amide IV \\
\hline & & 12 & & & & 742 & $\boldsymbol{R}_{\mathbf{z}}(\mathrm{NH})$ \\
\hline
\end{tabular}


Table 2 (cont.)

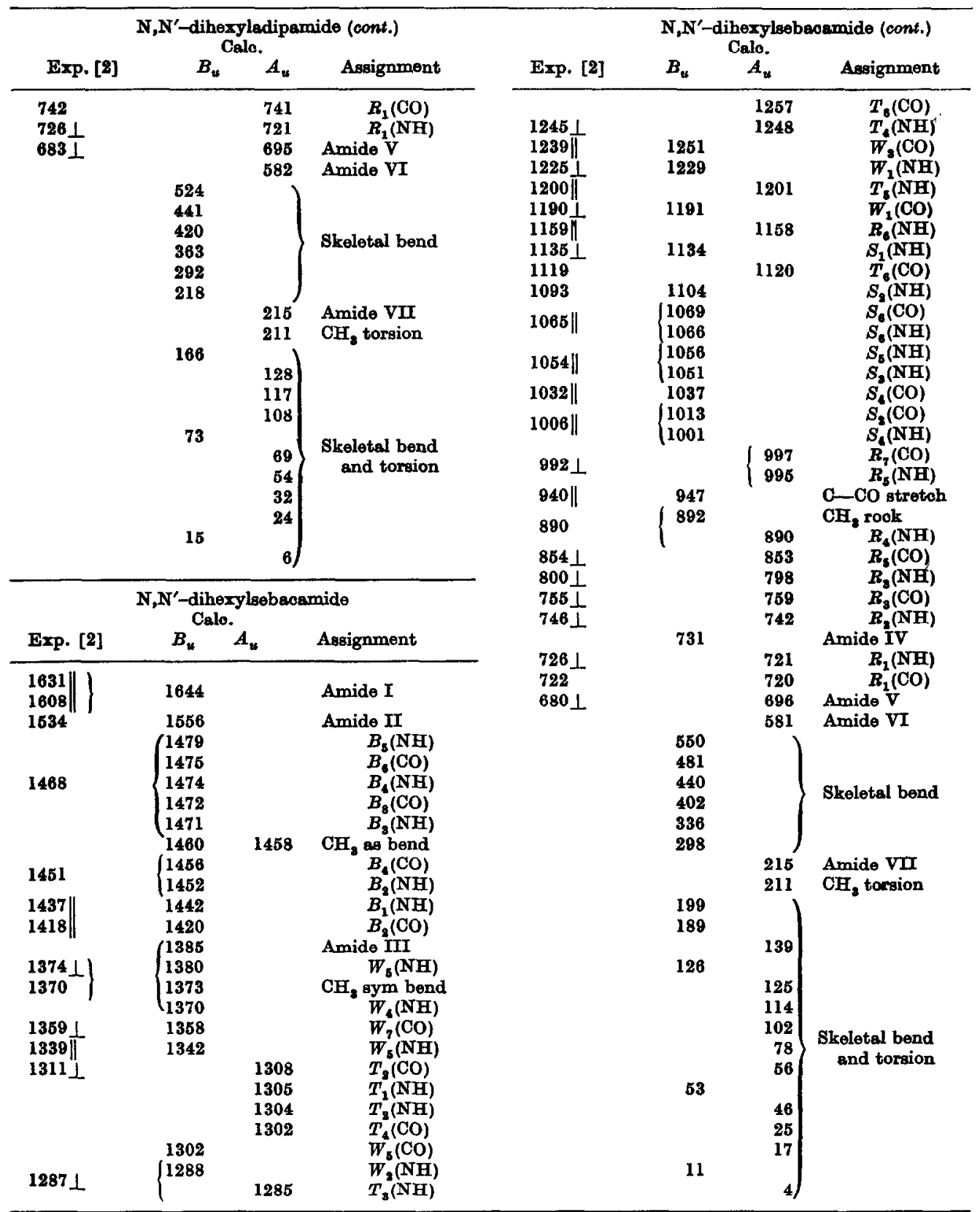

II: polarized parallel to cleavage plane.

$\perp$ : polarized perpendicular to cleavage plane.

While this does not fully define the structure, the overall pattern of polarizations suggests that the chain axes are essentially perpendicular to the plane of the thin crystal, with the $\mathrm{C}=\mathrm{O} \cdots \mathrm{H}-\mathrm{N}$ bonds being oriented predominantly parallel to the long dimension of the crystal. 
The observed bands are reproduced quite well by the present normal coordinate analysis. We should, however, note some problems. In hexamethylenedipropionamide the $\mathrm{CH}_{2}(\mathrm{CO})$ wagging frequency is off by more than $15 \mathrm{~cm}^{-1}$, probably due to the fact that no molecule with a $\mathrm{CH}_{3} \mathrm{CH}_{2} \mathrm{CO}$ - group was used in the force field refinement. Several deviations of about $10 \mathrm{~cm}^{-1}$ are also observed in the $\mathrm{C}-\mathrm{C}$ stretching region. Similar deviations occur in the spectra of the other two molecules. For the latter, the amide $\mathrm{V}$ band is completely absent in the parallel polarization, but the $\mathrm{CH}_{2}$ rocking bands still possess some intensity in this polarization. This may be due to the fact that the amide group is rotated slightly with respect to the polymethylene chain so that the transition moments of the amide $\mathrm{V}$ and $\mathrm{CH}_{2}$ rocking modes are not exactly parallel. A serious disagreement with the predicted polarization is the parallel polarization of the $R_{6}(\mathrm{NH})$ bands at 1156 and $1159 \mathrm{~cm}^{-1}$ in $\mathrm{N}, \mathrm{N}^{\prime}$-dihexyladipamide and $\mathrm{N}, \mathrm{N}^{\prime}$-dihexylsebacamide respectively. A possible explanation for this may be by analogy with the $1176 \mathrm{~cm}^{-1} T_{5}$ mode of nylon 6 , which is known to be strongly enhanced in intensity by rotation to the $\gamma$ form. If a small rotation occurs, which is probably the case, the 1156 and $1159 \mathrm{~cm}^{-1}$ bands may obtain some intensity from weak interaction with in-plane modes having parallel polarization.

A study of the polarized spectra of two sequences of diamides, namely $\left(\mathrm{CH}_{3}\right.$ $\left.\left(\mathrm{CH}_{2}\right)_{n} \mathrm{CONH}\left(\mathrm{CH}_{2}\right)_{m}\right)_{2}$ and $\left(\mathrm{CH}_{3}\left(\mathrm{CH}_{2}\right)_{n} \mathrm{NHCO}\left(\mathrm{CH}_{2}\right)_{m}\right)_{2}$ with varying $m$ and $n$, would be of great value in helping to remove the remaining uncertainties in the force field.

\section{$\mathrm{N}$-alkylamides}

The infrared spectra of some N-alkylamides, namely N-methyl, N-ethyl, Npropyl and $\mathrm{N}$-butyl derivatives of acetamide and propionamide, and of $\mathrm{N}$-nonylcapramide, were obtained by KessLer [2]. We calculated the dependence of vibrational frequencies on the torsion angle about the $\mathrm{CH}_{2}-\mathrm{NH}$ bond for $\mathrm{N}$-ethyl, $\mathrm{N}$-propyl and $\mathrm{N}$-butyl acetamide, and on the torsion angle about the $\mathrm{CH}_{2}-\mathrm{CO}$ bond for $\mathrm{N}$-methylpropionamide. The plots of these dependencies are shown in Fig. 2. For other derivatives of propionamide two torsions should be considered. We restricted ourselves to the planar form and to rotations about both bonds by the same angle of $45^{\circ}$ and $60^{\circ}$ in opposite directions (similar to that in the $\gamma$ form of nylon 6 ) and in the same direction. In the $\mathrm{N}$-nonylcapramide we omitted the rotation in the same direction. The experimental frequencies and those calculated for the planar form and for torsion angles of $45^{\circ}$ and $60^{\circ}$ are listed in Table 3 . An examination of this table shows that most of the infrared bands are well understood on the basis of the normal coordinate treatment. The difficulty with the $\mathrm{CH}_{2}(\mathrm{CO})$ bending mode met in the $\gamma$ form of nylon 6 still persists in the propionamide and capramide derivatives, and the same is true of the amide $\mathrm{V}$ band in $\mathrm{N}$-nonylcapramide. The main difficulty is in assigning the 1116 and $1119 \mathrm{~cm}^{-1}$ bands in $\mathrm{N}$-ethylacetamide and $\mathrm{N}$-ethylpropionamide respectively. Due to this fact, our confidence in the calculated frequencies of the propyl and butyl derivatives in the $1100 \mathrm{~cm}^{-1}$ region should also be lower. The cause for this may be the neglecting of the six force constants in the rotated isomers (see above), or the uncertainty in the force field due to ill-conditioning. In the region below $1000 \mathrm{~cm}^{-1}$ some hints of the possible existence of more than one conformer may be found in the presence of additional observed bands. In the liquid propyl 

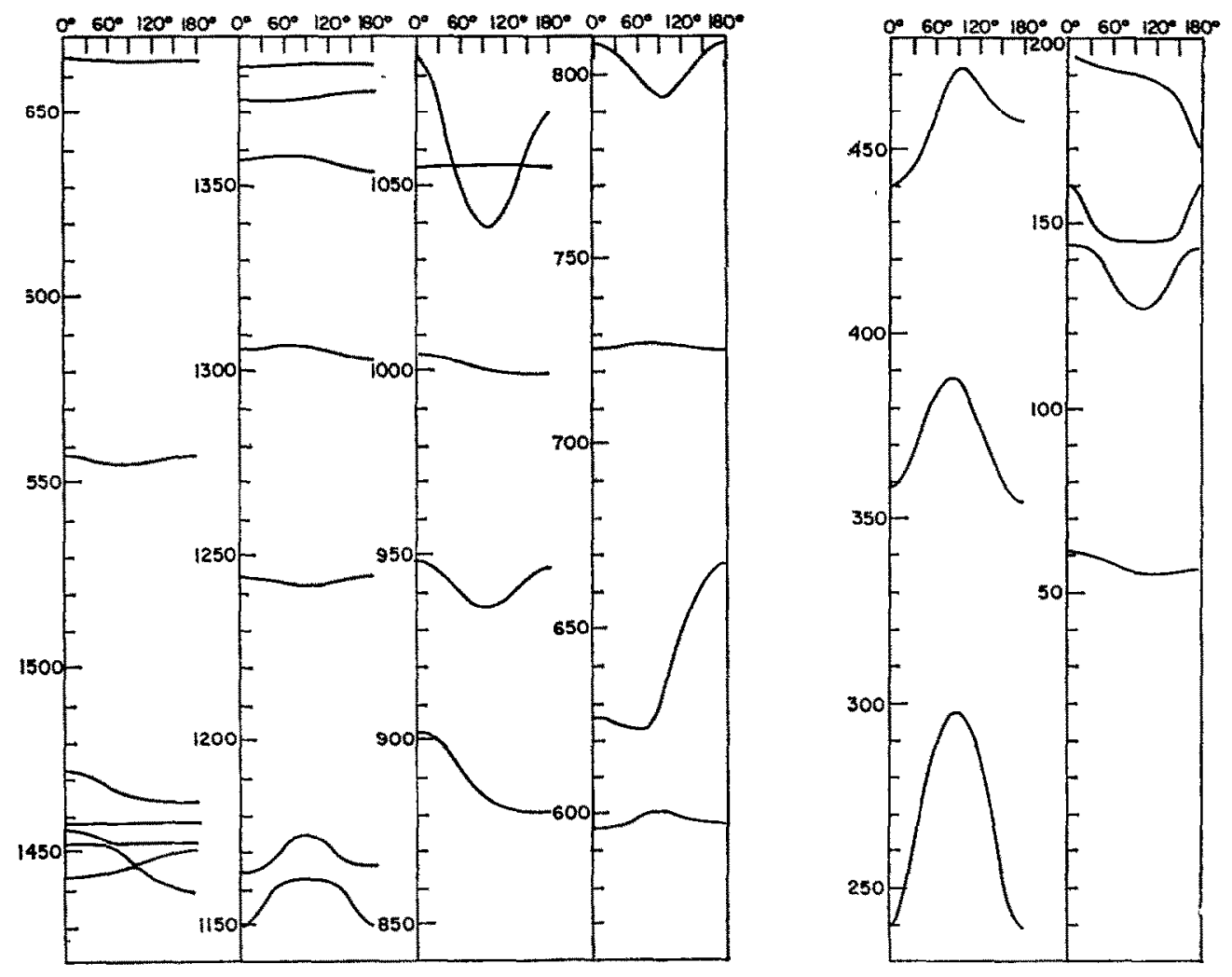

Fig. 2(a)

Fig. 2. The dependence of the frequencies on the torsion angle for $\mathrm{N}$-alkylamides. The dependence on the angle around the NH- $\mathrm{CH}_{2}$ bond is shown in cases (a)-(c) and on the angle around the $\mathrm{CO}-\mathrm{CH}_{2}$ bond in case (d). (a) N-ethylecetamide;

(b) N-propylacebamide; (c) N-butylacetamide; (d) N-methylpropionamide. 


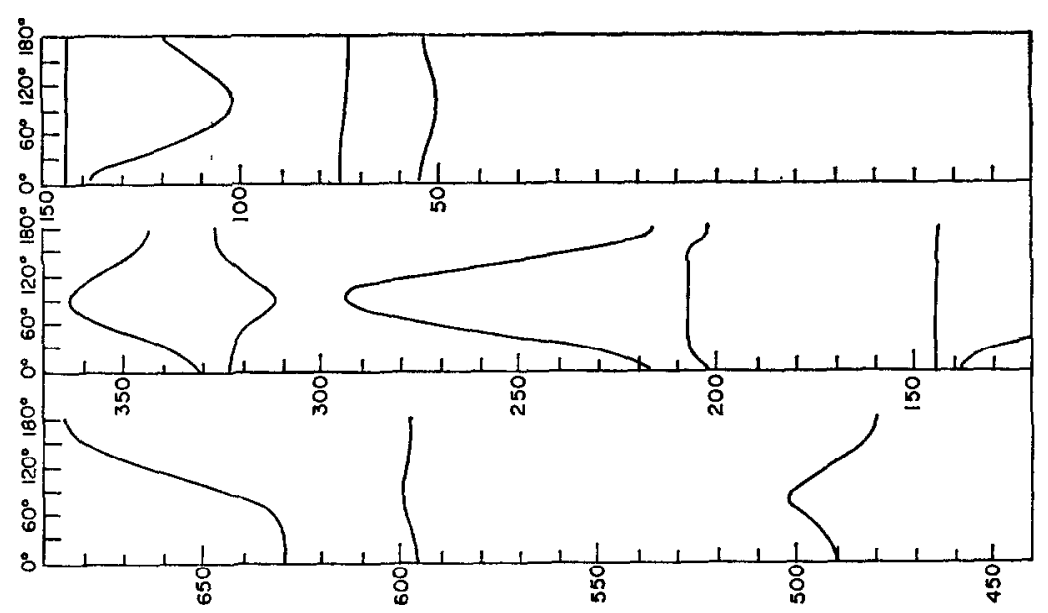

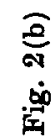

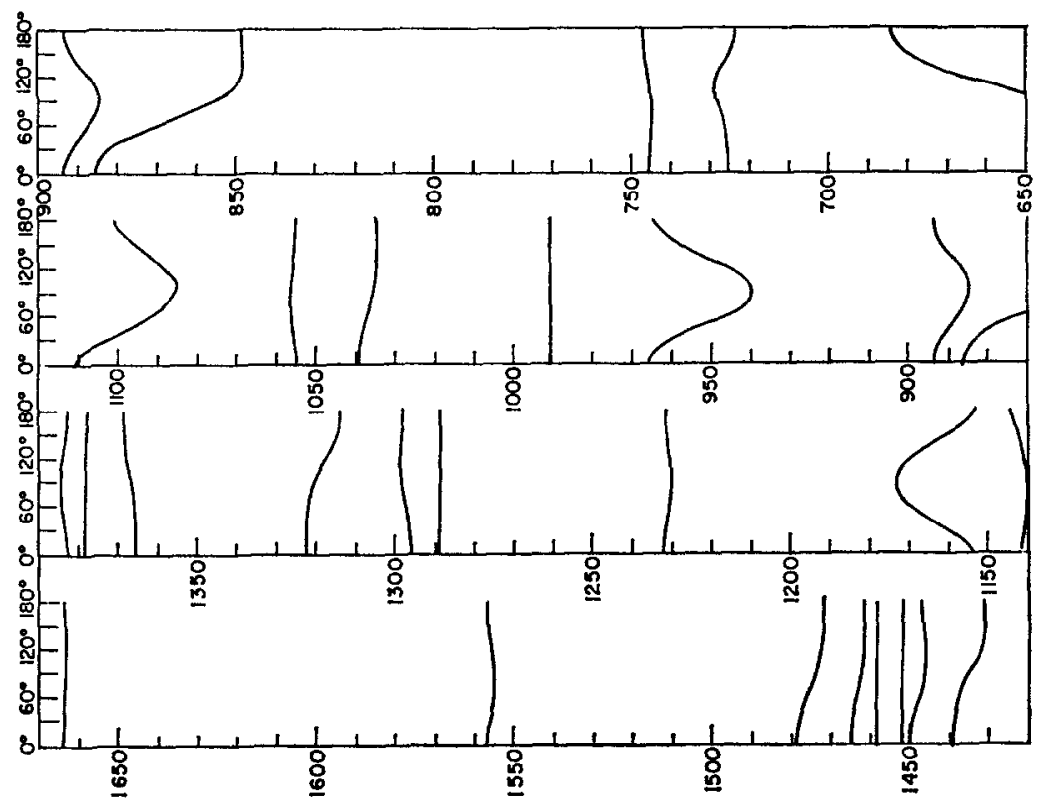




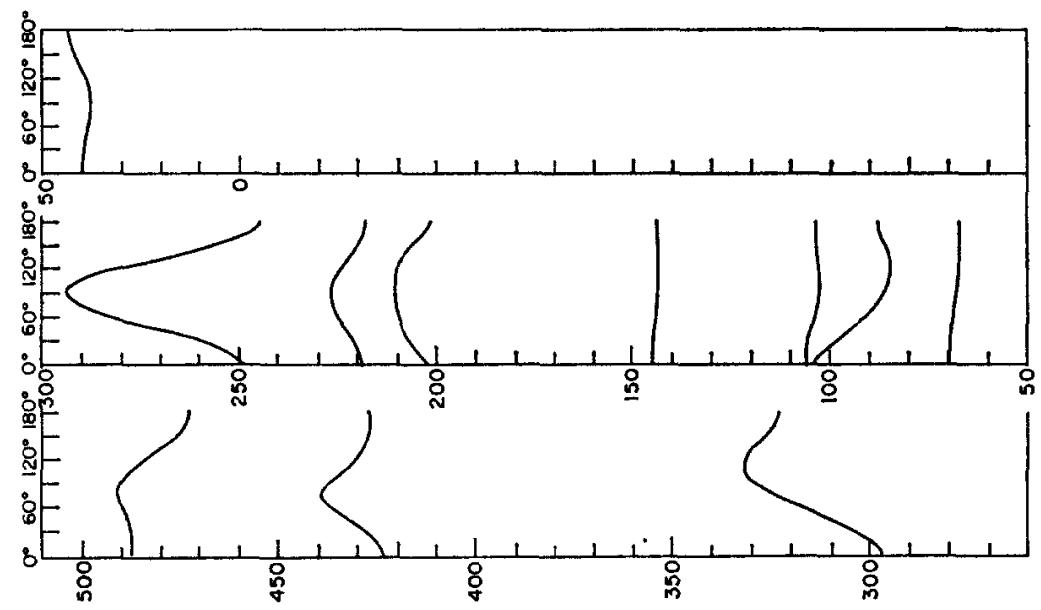

可

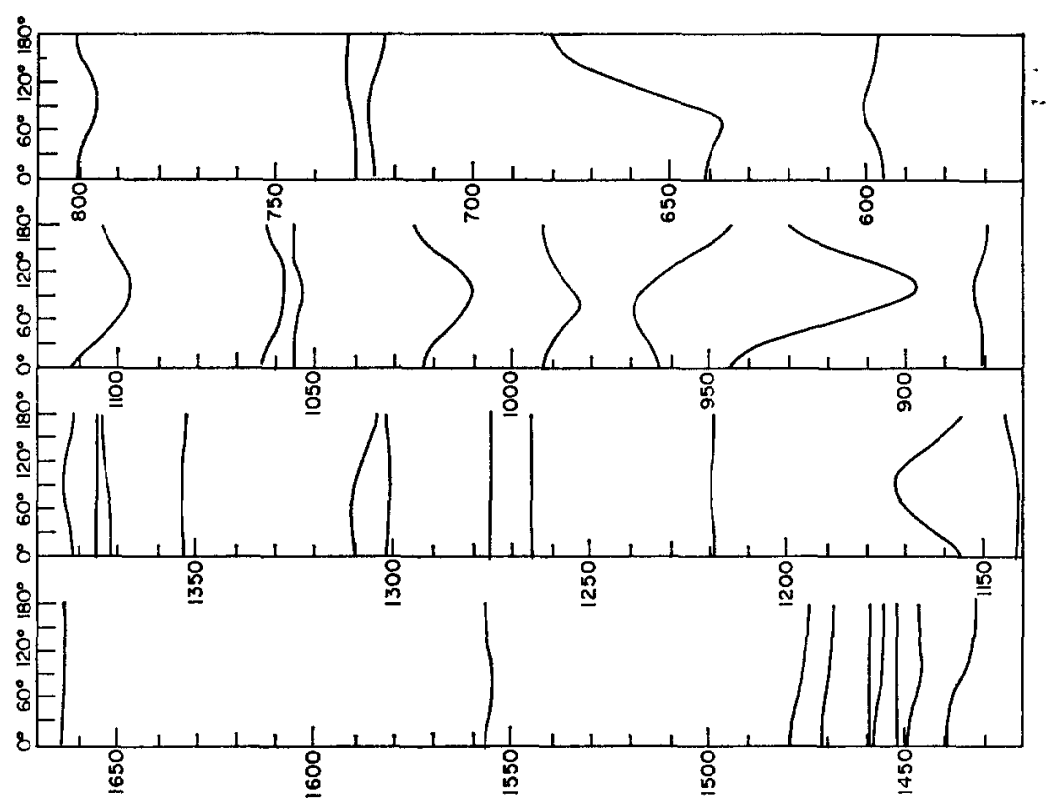



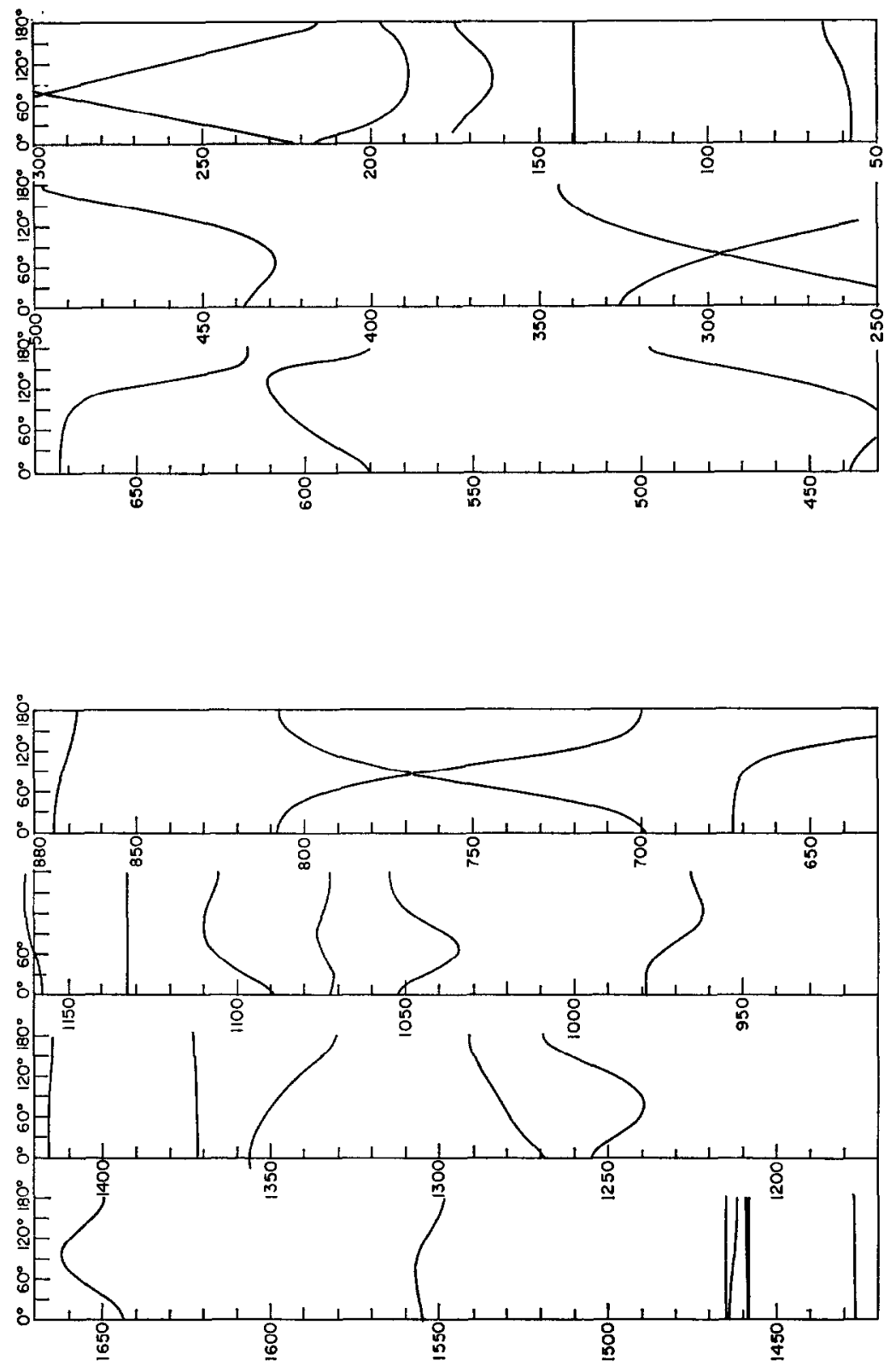

$\frac{8}{9}$
$\dot{0}$ 
Table 3. Experimental and calculated frequencies of some $\mathbf{N}$-alkylamides

\begin{tabular}{|c|c|c|c|c|c|}
\hline \multirow[b]{2}{*}{ Exp. [2] } & \multicolumn{2}{|c|}{$\phi=0^{\circ}$} & \multicolumn{2}{|c|}{$\begin{array}{l}\text { N-ethylacetamide } \\
\text { Calc. }\end{array}$} & \multirow[b]{2}{*}{ Assignment } \\
\hline & $A^{\prime}{ }^{\varphi}$ & $A^{\prime \prime}$ & $\phi=45^{\circ}$ & $\phi=60^{\circ}$ & \\
\hline 1653 & 1664 & & 1664 & 1663 & Amide I \\
\hline 1555 & 1557 & & 1555 & 1555 & Amide II \\
\hline \multirow[t]{2}{*}{1480} & 1472 & & 1469 & 1467 & CH, bend \\
\hline & & 1458 & 1458 & 1458 & $\mathrm{CH}_{3}\left(-\mathrm{CH}_{2}\right)$ as bend op \\
\hline \multirow[t]{2}{*}{1460} & 1456 & & 1454 & 1453 & $\mathrm{CH}_{2}\left(-\mathrm{CH}_{2}\right)$ as bend ip* \\
\hline & & 1452 & 1452 & 1462 & $\mathrm{CH}_{2}(-\mathrm{CO})$ as bend op \\
\hline 1439 & 1443 & & 1444 & 1444 & $\mathrm{CH}_{8}(-\mathrm{CO})$ as bend ip \\
\hline \multirow{2}{*}{1368} & $\{1382$ & & 1382 & 1383 & $\mathrm{CH}_{3}(-\mathrm{CO})$ sym bend \\
\hline & $\{1373$ & & 1373 & 1373 & $\mathrm{CH}_{8}\left(-\mathrm{CH}_{2}\right)$ sym bend \\
\hline 1351 & 1357 & & 1367 & 1358 & $\mathrm{CH}_{2}$ wag \\
\hline \multirow[t]{2}{*}{1292} & 1305 & & 1306 & 1306 & Amide III \\
\hline & & 1244 & 1243 & 1242 & $\mathrm{CH}_{\mathrm{g}}$ twist \\
\hline \multirow{2}{*}{$\begin{array}{l}1151 \\
1116\end{array}$} & 1164 & & 1159 & 1161 & $\mathrm{~N}-\mathrm{CH}_{2}$ stretch \\
\hline & & 1149 & 1168 & 1171 & $R_{2}$ \\
\hline 1073 & 1085 & & 1061 & 1050 & $\mathrm{CH}_{3}-\mathrm{CH}_{3}$ stretch \\
\hline 1041 & & 1055 & 1055 & 1056 & $\mathrm{CH}_{3}(-\mathrm{CO})$ rock op \\
\hline \multirow{2}{*}{$\begin{array}{r}1002 \\
947\end{array}$} & 1004 & & 1003 & 1002 & $\mathrm{CH}_{\mathrm{a}}(-\mathrm{CO})$ rock ip \\
\hline & \multicolumn{5}{|r|}{ का } \\
\hline \multirow{2}{*}{935} & 948 & & 942 & 939 & $\mathrm{CH}_{8}-\mathrm{CO}$ stretch \\
\hline & 902 & & 896 & 892 & $\mathrm{CH}_{8}\left(-\mathrm{CH}_{2}\right)$ rock ip \\
\hline 800 & & 808 & 803 & 799 & $R_{1}$ \\
\hline \multicolumn{6}{|l|}{775} \\
\hline \multirow{3}{*}{$\begin{array}{l}720 \\
620\end{array}$} & & 725 & 726 & 727 & Amide $\mathbf{V}$ \\
\hline & 626 & & 623 & 622 & Amide IV \\
\hline & & 596 & 597 & 699 & Amide VI \\
\hline \multirow{8}{*}{$\begin{array}{l}475 \\
427\end{array}$} & 440 & & 451 & 459) & \\
\hline & & & & & Skeletal bend \\
\hline & 359 & & 374 & 382) & \\
\hline & & 240 & 192 & 192 & $\mathrm{CH}_{3}-\mathrm{CH}_{2}$ torsion \\
\hline & 195 & & 274 & 287 & Skeletal bend \\
\hline & & 161 & 140 & 134 & Amide VII \\
\hline & & 144 & 147 & 145 & $\mathrm{CH}_{2}-\mathrm{CO}$ torsion \\
\hline & & 61 & 59 & $\mathbf{5 8}$ & $\mathrm{N}-\mathrm{CH}_{2}$ torsion \\
\hline
\end{tabular}

N-propylecetamide

Calo.

\begin{tabular}{|c|c|c|c|c|}
\hline Exp. [2] & $A^{\prime}{ }^{\phi}$ & $A^{\prime \prime}$ & $\phi=60^{\circ}$ & Assignment \\
\hline 1656 & 1664 & & 1663 & Amide I \\
\hline \multirow[t]{4}{*}{1555} & 1557 & & 1565 & Amide II \\
\hline & 1479 & & 1475 & $B_{2}$ \\
\hline & 1465 & & 1463 & $\mathrm{CH}_{3}\left(-\mathrm{CH}_{3}\right)$ as bend ip \\
\hline & & 1458 & 1458 & $\mathrm{CH}_{2}\left(-\mathrm{CH}_{2}\right)$ as bend op \\
\hline \multirow[t]{2}{*}{1460} & & 1452 & 1462 & $\mathrm{CH}_{3}(-\mathrm{CO})$ as bend op \\
\hline & 1450 & & 1447 & $B_{1}$ \\
\hline 1437 & 1439 & & 1437 & $\mathrm{CH}_{3}(-\mathrm{CO})$ as bend ip \\
\hline \multirow{4}{*}{1366} & $\{1383$ & & 1384 & $\mathrm{CH}_{8}(-\mathrm{CO})$ Bym bend \\
\hline & $\left\{\begin{array}{l}1378 \\
130\end{array}\right.$ & & 1379 & $\mathrm{CH}_{3}\left(-\mathrm{CH}_{2}\right)$ sym bend \\
\hline & 1366 & & 1366 & $w_{2}$ \\
\hline & 1322 & & 1322 & $w_{1}$ \\
\hline \multirow[t]{2}{*}{1289} & 1295 & & 1297 & Amide III \\
\hline & & 1289 & 1289 & $T_{2}$ \\
\hline \multirow[t]{2}{*}{1250} & & 1232 & 1231 & $T_{2}$ \\
\hline & & 1153 & 1170 & $R_{\text {s }}$ \\
\hline 1148 & 1141 & & 1140 & $\mathrm{~N}-\mathrm{CH}_{2}$ stretch \\
\hline $\left.\begin{array}{l}1111 \\
1098\end{array}\right\}$ & 1111 & & 1091 & $\mathrm{CH}_{2}-\mathrm{CH}_{2}$ strotah \\
\hline \multicolumn{5}{|l|}{1080} \\
\hline 1038 & & 1055 & 1056 & $\mathrm{CH}_{3}(-\mathrm{CO})$ rock op \\
\hline
\end{tabular}


Table 3 (cont.)

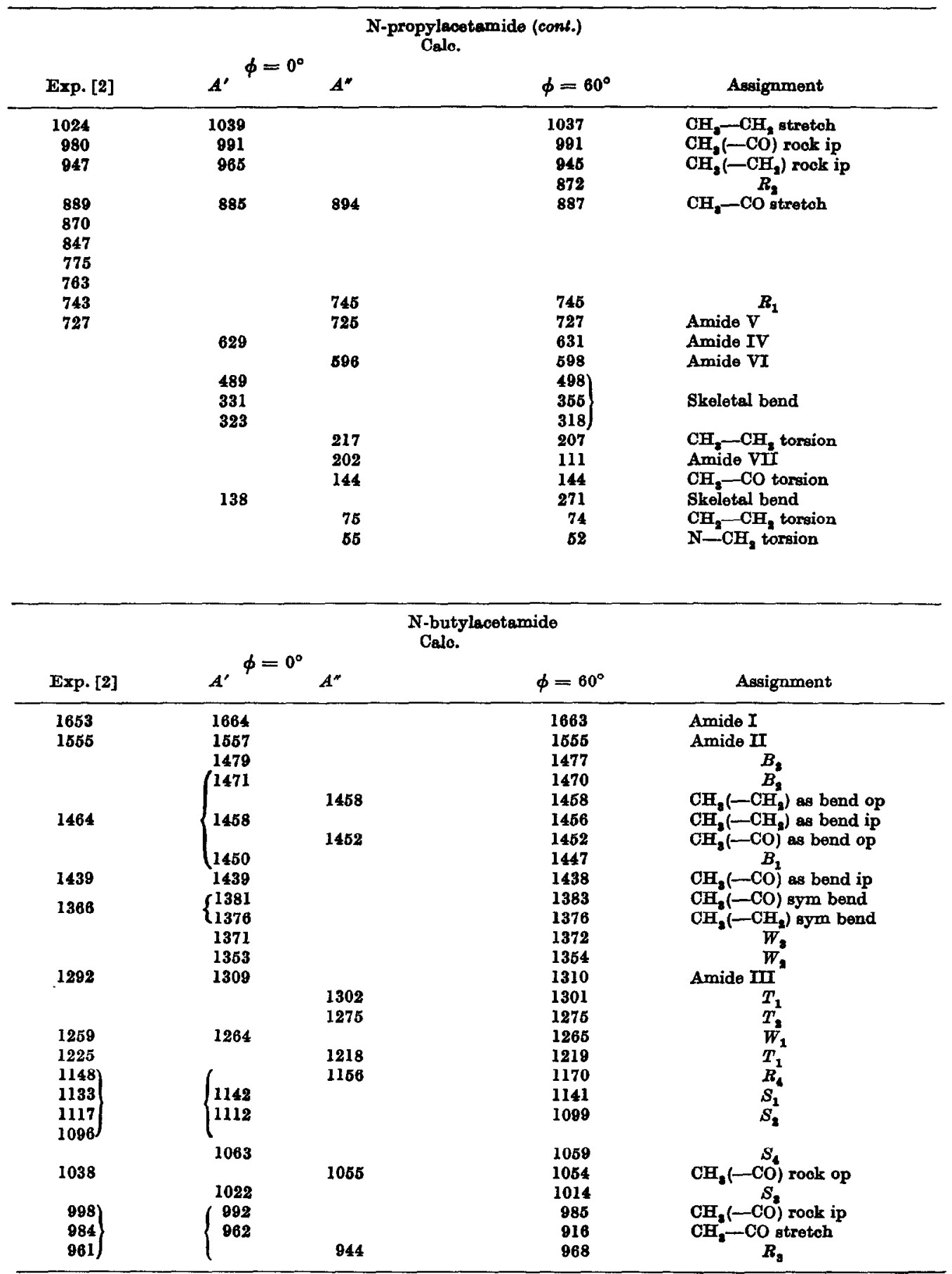


Table 3 (cont.)

\begin{tabular}{|c|c|c|c|c|c|}
\hline \multirow[b]{2}{*}{ Exp. [2] } & \multicolumn{4}{|c|}{ N-butylacetamide (cont.) } & \multirow[b]{2}{*}{ Assignment } \\
\hline & $A^{\prime}$ & $A^{\prime \prime}$ & & $\phi=60^{\circ}$ & \\
\hline \multirow[t]{2}{*}{886} & 880 & & & 881 & $\mathrm{CH}_{3}\left(-\mathrm{CH}_{2}\right)$ rock ip \\
\hline & & 800 & & 797 & $R_{2}$ \\
\hline 736 & & 729 & & 730 & $R_{1}$ \\
\hline 725 & & 725 & & 726 & Amide $\mathrm{V}$ \\
\hline \multirow[t]{2}{*}{620} & 641 & & & 637 & Amide IV \\
\hline & & 596 & & 599 & Amide VII \\
\hline \multicolumn{6}{|l|}{515} \\
\hline 600 & 487 & & & 489) & \\
\hline \multirow[t]{10}{*}{450} & 423 & & & 436 & Skeletal bend \\
\hline & 297 & & & 318 & \\
\hline & 249 & & & 282) & \\
\hline & & 218 & & 210 & $\mathrm{CH}_{2}-\mathrm{CH}_{2}$ torsion \\
\hline & & 202 & & 91 & Amide VII \\
\hline & & 145 & & 144 & $\mathrm{CH}_{2}-\mathrm{CO}$ torsion \\
\hline & & 106 & & 104 & $\mathrm{CH}_{2}-\mathrm{CH}_{2}$ torsion \\
\hline & 104 & & & 225 & Skeletal bend \\
\hline & & 70 & & 69 & $\mathrm{CH}_{2}-\mathrm{CH}_{2}$ torsion \\
\hline & & 40 & & 38 & $\mathrm{CH}_{2}-\mathrm{N}$ torsion \\
\hline \multicolumn{6}{|c|}{ N-methylpropionamide } \\
\hline Exp. [2] & $A^{\prime}$ & $A^{\prime \prime}$ & $\phi=45^{\circ}$ & $\phi=60^{\circ}$ & Assignment \\
\hline 1653 & 1644 & & 1652 & 1657 & Amide I \\
\hline 1560 & 1556 & & 1557 & 1567 & Amide II \\
\hline & & 1465 & 1465 & 1465 & $\mathrm{CH}_{3}(-\mathrm{NH})$ as bend op \\
\hline & 1464 & & 1464 & 1463 & $\mathrm{CH}_{3}(-\mathrm{NH})$ as bend ip \\
\hline 1464 & & 1458 & 1458 & 1458 & $\mathrm{CH}_{2}\left(-\mathrm{CH}_{2}\right)$ as bend op \\
\hline & 1458 & & 1458 & 1459 & $\mathrm{CH}_{3}\left(-\mathrm{CH}_{2}\right)$ as bend ip \\
\hline & 1427 & & 1427 & 1427 & $\mathrm{CH}_{2}$ bend \\
\hline 1410 & 1416 & & 1416 & 1416 & $\mathrm{CH}_{\mathrm{a}}^{\mathrm{a}}(-\mathrm{NH})$ sym bend \\
\hline 1368 & $137\}$ & & 1372 & 1372 & $\mathrm{CH}_{3}\left(-\mathrm{CH}_{2}\right)$ sym bend \\
\hline 1272 & |1356 & & 1354 & 1352 & Amide III \\
\hline 1272 & & 1269 & 1277 & 1279 & $\mathrm{CH}_{2}$ twist \\
\hline 1236 & 1255 & & 1243 & 1240 & $\mathrm{CH}_{\mathbf{2}}$ wag \\
\hline 1160 & 1158 & & 1159 & 1160 & $\mathrm{CH}_{3}(-\mathrm{NH})$ rock ip \\
\hline 1109 & & 1133 & 1133 & 1133 & $\mathrm{CH}_{\mathrm{a}}(-\mathrm{NH})$ rock op \\
\hline 30 & 1089 & & 1103 & 1107 & $\mathrm{CH}_{3}-\mathrm{NH}$ stretch \\
\hline 1068 & & 1072 & 1073 & 1074 & $R_{2}$ \\
\hline 1045 & 1052 & & 1038 & 1034 & $\mathrm{CH}_{2}\left(-\mathrm{CH}_{2}\right)$ rock ip \\
\hline 971 & 979 & & 977 & 975 & $\mathrm{CH}_{8}-\mathrm{CH}_{2}$ stretch \\
\hline 867 & 874 & & 874 & 873 & $\mathrm{CH}_{2}-\mathrm{CO}$ stretch \\
\hline 805 & & 808 & 800 & 792 & $R_{1}$ \\
\hline 699 & & 699 & 722 & 672 & Amide V \\
\hline & 673 & & 672 & 738 & Amide IV \\
\hline & & 681 & 594 & 599 & Amide VI \\
\hline & 438 & & 431 & 429) & \\
\hline & 326 & & 315 & 307 & Skeletal bend \\
\hline & 223 & & 266 & 281) & \\
\hline & & 217 & 194 & 191 & $\mathrm{CH}_{3}-\mathrm{CH}_{2}$ torsion \\
\hline & & 177 & 171 & 168 & Amide VII \\
\hline & & 139 & 139 & 139 & $\mathrm{CH}_{\mathrm{s}}-\mathrm{NH}$ torsion \\
\hline & & 58 & 58 & 58 & $\mathrm{CH}_{2}-\mathrm{CO}$ torsion \\
\hline
\end{tabular}


Table 3 (cont.)

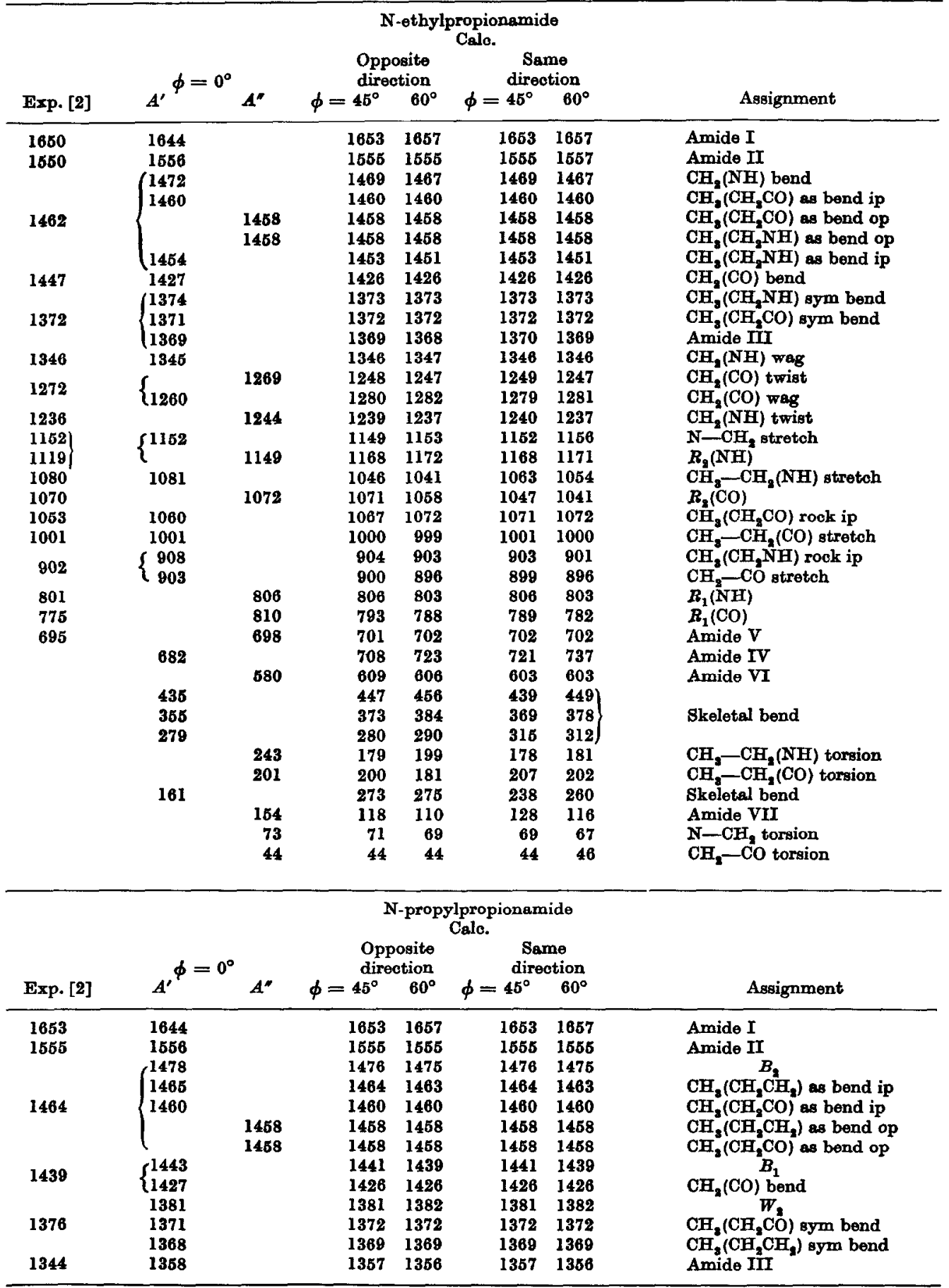


Table 3 (cont.)

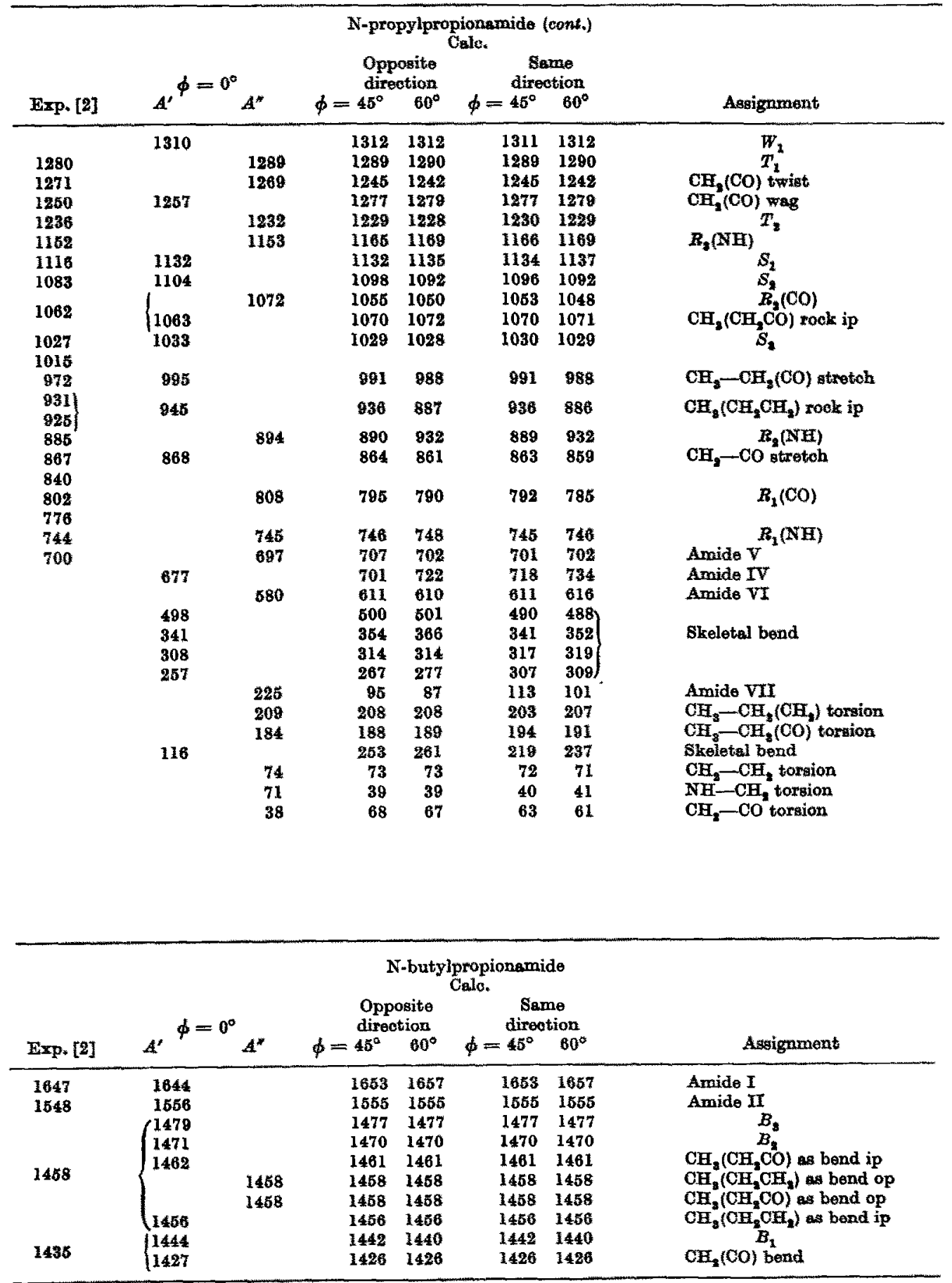


Table 3 (cont.)

\begin{tabular}{|c|c|c|c|c|c|c|c|}
\hline \multirow[b]{3}{*}{$\operatorname{Exp} \cdot[2]$} & \multirow{3}{*}{\multicolumn{2}{|c|}{$A^{\prime}{ }^{\phi}=0^{\circ}{ }_{A^{\prime \prime}}$}} & \multicolumn{4}{|c|}{ N-butylpropionamide (cont.) } & \multirow[b]{3}{*}{ Assignment } \\
\hline & & & \multicolumn{2}{|c|}{$\begin{array}{l}\text { Opposite } \\
\text { direction }\end{array}$} & \multicolumn{2}{|c|}{$\begin{array}{c}\text { Same } \\
\text { direction }\end{array}$} & \\
\hline & & & $\phi=45^{\circ}$ & $60^{\circ}$ & $\phi=45^{\circ}$ & $60^{\circ}$ & \\
\hline & $(1376$ & & 1376 & 1376 & 1376 & 1376 & $\mathrm{CH}_{3}\left(\mathrm{CH}_{2} \mathrm{CH}_{2}\right)$ sym bend \\
\hline & 1374 & & 1374 & 1375 & 1375 & 1375 & \\
\hline 1366 & 1371 & & 1372 & 1372 & 1372 & 1372 & $\mathrm{CH}_{8}\left(\mathrm{CH}_{2} \mathrm{CO}\right)$ sym bend \\
\hline & 1364 & & 1363 & 1362 & 1363 & 1362 & Amide III \\
\hline & 1346 & & 1347 & 1347 & 1347 & 1347 & $W_{2}$ \\
\hline & & 1302 & 1302 & 1302 & 1302 & 1302 & $T_{1}^{*}$ \\
\hline 1265 & $(1275$ & & 1285 & 1265 & 1260 & 1266 & $W_{1}$ \\
\hline 1235 & & 1276 & 1274 & 1274 & 1275 & 1275 & $T_{2}^{2}$ \\
\hline & & 1269 & 1242 & 1240 & 1242 & 1240 & $\mathrm{CH}_{2}(\mathrm{CO})$ twist \\
\hline & 1250 & & 1284 & 1286 & 1283 & 1285 & $\mathrm{CH}_{2}(\mathrm{CO})$ wag \\
\hline & & 1218 & 1217 & 1217 & 1218 & 1217 & $T_{3}$ \\
\hline 1148 & & 1155 & 1166 & 1168 & 1166 & 1169 & $R_{\mathrm{d}}(\mathrm{NH})$ \\
\hline 1127 & 1134 & & 1134 & 1137 & 1136 & 1139 & $S_{1}$ \\
\hline $\begin{array}{l}1114 \\
1100\end{array}$ & 1103 & & 1103 & 1101 & & 1100 & \\
\hline 1100 & & 1072 & 1047 & 1042 & 1046 & 1041 & $R_{,}(\mathrm{CO})$ \\
\hline 1063 & $\{1066$ & & 1061 & 1059 & 1061 & 1059 & $S_{1}$ \\
\hline & 1057 & & 1070 & 1072 & 1070 & 1071 & $\mathrm{CH}_{3}\left(\mathrm{CH}_{2} \mathrm{CO}\right)$ rock ip \\
\hline 1033 & & & & & & & \\
\hline & 1019 & & 1011 & 1009 & 1012 & 1011 & $S_{2}$ \\
\hline $\begin{array}{r}1000 \\
970\end{array}$ & 1002 & & 998 & 993 & 998 & 991 & $\mathrm{CH}_{2}-\mathrm{CH}_{2}(\mathrm{CO})$ stretch \\
\hline 948 & & 944 & 951 & 953 & 948 & 951 & $R_{2}(\mathrm{NH})$ \\
\hline & 926 & & 874 & 873 & 873 & 873 & $\mathrm{CH}_{2}-\mathrm{CO}$ stretch \\
\hline 901 & & & & & & & \\
\hline 877 & 874 & & $\begin{array}{l}913 \\
793\end{array}$ & $\begin{array}{l}906 \\
789\end{array}$ & $\begin{array}{l}913 \\
790\end{array}$ & 906 & $\mathrm{CH}_{3}\left(\mathrm{CH}_{2} \mathrm{CH}_{2}\right)$ rook ip \\
\hline 803 & & $\begin{array}{l}808 \\
800\end{array}$ & 801 & $\begin{array}{l}789 \\
790\end{array}$ & $\begin{array}{l}790 \\
801\end{array}$ & $\begin{array}{l}784 \\
799\end{array}$ & $R_{1}(\mathrm{NH})$ \\
\hline 740 & & & & & & & \\
\hline 735 & & $\begin{array}{l}729 \\
697\end{array}$ & 730 & 732 & 730 & 728 & $R_{1}(\mathrm{NH})$ \\
\hline 701 & & 697 & 701 & 702 & 702 & 703 & Amide V \\
\hline & 684 & & 709 & 722 & 719 & 737 & Amide IV \\
\hline & & $\mathbf{5 8 0}$ & 616 & 616 & 614 & 617 & Amide VI \\
\hline & 500 & & 492 & 489 & 485 & 479) & \\
\hline & 423 & & 432 & 436 & 431 & 438 & \\
\hline & 297 & & 312 & 329 & 313 & 312 & Skeletal bend \\
\hline & 278 & & 289 & 289 & 296 & $306)$ & \\
\hline & & 226 & 206 & 207 & 196 & 200 & Amide VII \\
\hline & 216 & & 258 & 267 & 254 & 271 & Skeletal bend \\
\hline & & & 212 & 211 & 214 & 213 & $\mathrm{CH}_{2}-\mathrm{CH}_{2}\left(\mathrm{CH}_{2}\right)$ torsion \\
\hline & & 184 & 188 & 188 & 192 & 191 & $\mathrm{CH}_{2}-\mathrm{CH}_{2}(\mathrm{CO})$ torsion \\
\hline & & 108 & 105 & 104 & 104 & 103 & $\mathrm{CH}_{3}-\mathrm{CH}_{3}\left(\mathrm{CH}_{2}\right)$ toraion \\
\hline & 88 & & 76 & 72 & 93 & 85 & Skelotal bend \\
\hline & & 70 & 68 & 67 & 65 & 64 & $\mathrm{CH}_{2}-\mathrm{CH}_{2}(\mathrm{NH})$ toraion \\
\hline & & 62 & 61 & 60 & 57 & 56 & $\mathrm{CH}_{3}-\mathrm{CO}$ torsion \\
\hline & & 30 & 30 & 30 & 31 & 32 & $\mathrm{CH}_{3}-\mathrm{NH}$ torsion \\
\hline
\end{tabular}


Table 3 (cont.)

\begin{tabular}{|c|c|c|c|c|c|}
\hline \multirow[b]{2}{*}{ Exp. [2] } & \multicolumn{4}{|c|}{$\begin{array}{l}\text { N-nonylcapramide } \\
\text { Cale. } \\
\\
\text { Opposite } \\
\text { direotion }\end{array}$} & \multirow[b]{2}{*}{ Assignment } \\
\hline & $A^{\prime}$ & $A^{\prime \prime}$ & $\phi=45^{\circ}$ & $\phi=60^{\circ}$ & \\
\hline \multirow{6}{*}{$\begin{array}{l}1642 \\
1563\end{array}$} & 1644 & & 1653 & 1657 & Amide I \\
\hline & 1556 & & 1555 & 1555 & Amide II \\
\hline & 1479 & & 1478 & 1477 & $B_{\mathrm{s}}(\mathrm{NE})$ \\
\hline & 1475 & & 1475 & 1475 & $B_{3}(\mathrm{NH})$ \\
\hline & 1474 & & 1474 & 1474 & $B_{\mathrm{g}}(\mathrm{NE})$ \\
\hline & 1474 & & 1474 & 1474 & $B_{4}(\mathrm{CO})$ \\
\hline \multirow[t]{11}{*}{1464} & 1473 & & 1473 & 1473 & $B_{7}(\mathrm{NH})$ \\
\hline & 1471 & & 1471 & 1471 & $B_{8}(\mathrm{CO})$ \\
\hline & 1468 & & 1467 & 1467 & $B_{1}(\mathrm{NH})$ \\
\hline & 1460 & & 1460 & 1460 & $\mathrm{CH}_{\mathrm{g}}(\mathrm{NH})$ as bend ip \\
\hline & 1460 & & 1460 & 1460 & $\mathrm{CH}_{3}(\mathrm{CO})$ as bend ip \\
\hline & & 1458 & 1468 & 1458 & $\mathrm{CH}_{8}(\mathrm{NH})$ as bend op \\
\hline & & 1468 & 1458 & 1458 & $\mathrm{CH}_{8}(\mathrm{CO})$ as bend op \\
\hline & $14 \overline{6} 4$ & & 1454 & 1453 & $B_{8}(\mathrm{NH})$ \\
\hline & 1451 & & 1451 & 1451 & $B_{2}(\mathrm{CO})$ \\
\hline & 1446 & & 1445 & 1445 & $\mathrm{~B}_{8}(\mathrm{NH})$ \\
\hline & 1441 & & 1430 & 1438 & $B_{1}(\mathrm{NH})$ \\
\hline \multirow[t]{4}{*}{1433} & 1420 & & 1420 & 1420 & $B_{1}(\mathrm{CO})$ \\
\hline & 1385 & & 1385 & 1385 & $W_{4}(\mathrm{CO})$ \\
\hline & 1384 & & 1384 & 1384 & $W_{B}(\mathrm{NH})$ \\
\hline & 1378 & & 1378 & 1378 & $W_{7}(\mathrm{NH})$ \\
\hline \multirow[t]{4}{*}{1376} & 1376 & & 1376 & 1376 & $\mathrm{OH}_{3}(\mathrm{CO})$ sym bend \\
\hline & 1373 & & 1378 & 1873 & $\mathrm{CH}_{3}(\mathrm{NH})$ sym bend \\
\hline & 1370 & & 1370 & 1370 & $W_{6}(\mathrm{NE})$ \\
\hline & 1363 & & 1362 & 1382 & Amide III \\
\hline 1350 & 1351 & & 1352 & 1352 & $W_{s}(\mathrm{NH})$ \\
\hline \multirow[t]{4}{*}{1320} & 1324 & & 1325 & 1325 & $W_{4}$ (NA) \\
\hline & 1315 & & 1316 & 1317 & $W_{3}(\mathrm{CO})$ \\
\hline & & 1308 & 1308 & 1308 & $T_{\mathrm{B}}(\mathrm{NH})$ \\
\hline & & 1308 & 1308 & 1308 & $T_{2}(\mathrm{NH})$ \\
\hline \multirow[t]{5}{*}{1287} & & 1305 & 1305 & 1305 & $T_{2}(\infty 0)$ \\
\hline & & 1303 & 1301 & 1300 & $T_{2}(\mathrm{CO})$ \\
\hline & & 1302 & 1302 & 1302 & $T_{1}(\mathrm{NH})$ \\
\hline & & 1299 & 1290 & 1299 & $T_{4}(\mathrm{NH})$ \\
\hline & 1287 & & 1287 & 1287 & $W_{3}(\mathrm{NH})$ \\
\hline \multirow[t]{3}{*}{1285} & & & & & \\
\hline & 2 & 1282 & 1282 & 1282 & $T_{5}(\mathrm{NH})$ \\
\hline & & 1272 & 1262 & 1260 & $T_{\mathrm{a}}(\mathrm{CO})$ \\
\hline 1264 & $\{1267$ & & 1270 & 1277 & $W_{a}(\mathrm{CO})$ \\
\hline 1258 & & 1256 & 1255 & 1255 & $T_{\theta}(\mathrm{NH})$ \\
\hline 1248 & 1250 & & 1249 & 1250 & $W_{2}(\mathrm{NH})$ \\
\hline 1238 & & 1224 & 1226 & 1221 & $T_{7}(\mathrm{NH})$ \\
\hline 1222 & 1219 & & 1220 & 1227 & $w_{1}(\mathrm{CO})$ \\
\hline \multirow{2}{*}{1202} & 1209 & & 1210 & 1210 & $W_{\lambda}(\mathrm{NH})$ \\
\hline & & 1206 & 1202 & 1201 & $T_{4}(\mathrm{CO})$ \\
\hline \multirow{7}{*}{$\begin{array}{l}1185 \\
1160 \\
1127 \\
1119\end{array}$} & & 1188 & 1189 & 1189 & $T_{8}(\mathrm{NH})$ \\
\hline & & 1169 & 1160 & 1108 & $R_{0}(\mathrm{NH})$ \\
\hline & 1135 & & 1137 & 1139 & $s_{1}(\mathrm{NE})$ \\
\hline & 1121 & & 1114 & 1116 & $s_{1}(C O)$ \\
\hline & & 1104 & 1083 & 1077 & $\boldsymbol{R}_{6}(\mathrm{CO})$ \\
\hline & 1100 & & 1121 & 1120 & $S_{2}(\mathrm{NE})$ \\
\hline & 1079 & & 1065 & 1062 & $S_{\mathbf{g}}(\mathbf{N H})$ \\
\hline \multirow{5}{*}{1071} & 1086 & & 1070 & 1068 & $S_{9}(\mathrm{NH})$ \\
\hline & 1084 & & 1064 & 1065 & $S_{\mathrm{g}}(\mathrm{NH})$ \\
\hline & 1002 & & 1009 & 1063 & $S_{4}(00)$ \\
\hline & 1060 & & 1058 & 1055 & $S_{7}(\mathbf{N H})$ \\
\hline & 1050 & & 1050 & 1049 & $S_{8}(C O)$ \\
\hline
\end{tabular}


Table 3 (cont.)

\begin{tabular}{|c|c|c|c|c|c|}
\hline \multirow[b]{2}{*}{ Exp. [2] } & \multicolumn{2}{|c|}{$h=0^{\circ}$} & \multicolumn{2}{|c|}{$\begin{array}{l}\text { Opposite } \\
\text { direction }\end{array}$} & \multirow[b]{2}{*}{ Assignment } \\
\hline & $A^{*}{ }^{\Psi}$ & $A^{\prime \prime}$ & $\phi=45^{\circ}$ & $\phi=60^{\circ}$ & \\
\hline 1022 & $\{1031$ & 1027 & $\begin{array}{l}1030 \\
1029\end{array}$ & $\begin{array}{l}1030 \\
1030\end{array}$ & $\begin{array}{l}S_{6}(\mathrm{NH}) \\
R_{8}(\mathrm{NH})\end{array}$ \\
\hline 1015 & 1015 & & 1005 & $\begin{array}{r}999 \\
1010\end{array}$ & $\begin{array}{l}S_{4}(\mathrm{NH}) \\
S_{2}(\mathrm{CO})\end{array}$ \\
\hline 993 & 989 & 960 & $\begin{array}{l}991 \\
966\end{array}$ & $\begin{array}{l}991 \\
969\end{array}$ & $\begin{array}{l}S_{5}(\mathrm{NH}) \\
R_{7}(\mathrm{NH})\end{array}$ \\
\hline 966 & & 957 & 953 & 952 & $R_{4}(\mathrm{CO})$ \\
\hline 929 & $\begin{array}{l}951 \\
894\end{array}$ & & $\begin{array}{l}943 \\
896\end{array}$ & $\begin{array}{l}936 \\
897\end{array}$ & $\begin{array}{l}\mathrm{CH}_{2} \mathrm{CO} \text { stretch } \\
\mathrm{CH}_{3}(\mathrm{CO}) \text { rock ip }\end{array}$ \\
\hline 888 & 891 & 888 & 891 & $\begin{array}{l}891 \\
881\end{array}$ & $\begin{array}{c}\mathrm{CH}_{3}(\mathrm{NH}) \text { rock ip } \\
R_{8}(\mathrm{NH})\end{array}$ \\
\hline & & 845 & 841 & 837 & $R_{3}(\mathrm{CO})$ \\
\hline 820 & & $\begin{array}{l}823 \\
773\end{array}$ & $\begin{array}{l}824 \\
775\end{array}$ & $\begin{array}{l}824 \\
777\end{array}$ & $\begin{array}{l}R_{5}(\mathrm{NH}) \\
\boldsymbol{R}_{6}(\mathrm{NH})\end{array}$ \\
\hline $\begin{array}{l}758 \\
740\end{array}$ & & $\begin{array}{l}766 \\
741\end{array}$ & $\begin{array}{l}767 \\
744\end{array}$ & $\begin{array}{l}767 \\
739\end{array}$ & $\begin{array}{l}R_{2}(\mathrm{CO}) \\
R_{2}(\mathrm{NH})\end{array}$ \\
\hline & 733 & & 737 & 746 & Amide IV \\
\hline 721 & & $\begin{array}{l}726 \\
725 \\
718\end{array}$ & $\begin{array}{l}722 \\
725 \\
718\end{array}$ & $\begin{array}{l}721 \\
725 \\
718\end{array}$ & $\begin{array}{l}R_{1}(\mathrm{CO}) \\
R_{2}(\mathrm{NH}) \\
R_{1}(\mathrm{NH})\end{array}$ \\
\hline 715 & & $\begin{array}{l}696 \\
581\end{array}$ & $\begin{array}{l}693 \\
612\end{array}$ & $\begin{array}{l}690 \\
623\end{array}$ & $\begin{array}{l}\text { Amide V } \\
\text { Amide VI }\end{array}$ \\
\hline & 541 & & 531 & 532 & \\
\hline & 490 & & 494 & 496 & \\
\hline & 486 & & 473 & 466 & \\
\hline & 428 & & 431 & 433 & \\
\hline & 398 & & 394 & 392 & Skeletal bend \\
\hline & $\mathbf{3 7 0}$ & & $\mathbf{3 7 7}$ & $\mathbf{3 7 9}$ & \\
\hline & 307 & & 319 & 328 & \\
\hline & 272 & & 276 & 282 & \\
\hline & 231 & & 255 & 267) & \\
\hline & & 215 & 112 & 113 & Amide VII \\
\hline & & 212 & 212 & 212 & $\mathrm{CH}_{8}-\mathrm{CH}_{2}(\mathrm{NH})$ torsion \\
\hline & & 211 & 212 & 212 & $\mathrm{CH}_{3}-\mathrm{CH}_{2}(\mathrm{CO})$ torsion \\
\hline & 177 & & 233 & 234) & Skelatel bend \\
\hline & 142 & & 166 & 169 & Skeletal bend \\
\hline & & 141 & 141 & 141) & \\
\hline & & 134 & 133 & 134 & Slolot tongion \\
\hline & & 119 & 119 & 119 & Skeletal torsion \\
\hline & & 111 & 108 & $108)$ & \\
\hline & 109 & & 160 & 160 & Skeletal bend \\
\hline & & 104 & 98 & 967 & \\
\hline & & 86 & 87 & 88 & \\
\hline & & 73 & 70 & 68 & \\
\hline & 61 & & 62 & 62 & \\
\hline & & 62 & 49 & 48 & Skeletal torsion and bend \\
\hline & & 48 & 46 & 45 & \\
\hline & & 32 & 32 & 32 & \\
\hline & & 25 & 24 & 24 & \\
\hline & 23 & & 21 & 21 & \\
\hline & & 9 & 9 & 10 & \\
\hline
\end{tabular}

* op = out-of-plane; ip $=$ in plane. 
and butyl derivatives, the presence of other than trans rotamers about $\mathrm{CH}_{2}-\mathrm{CH}_{2}$ bonds should be considered, although most probably their amount is small.

\section{$\mathrm{C}$-deuterated nylon 66}

The NH-vicinal and CO-vicinal C-deuterated derivatives of nylon 66 were obtained, and their infrared spectra measured, by HoIDEMANN and ZAHN [3]. The calculation of infrared active frequencies of these molecules was performed, and the calculated and observed values are compared in Table 4. In the NH-vicinal deuterated derivative, the agreement is good and comparable with other molecules calculated here. A different situation occurs with the other derivative. Here, for the

Table 4. Experimental and calculated frequencies of C-deuterated nylon 66

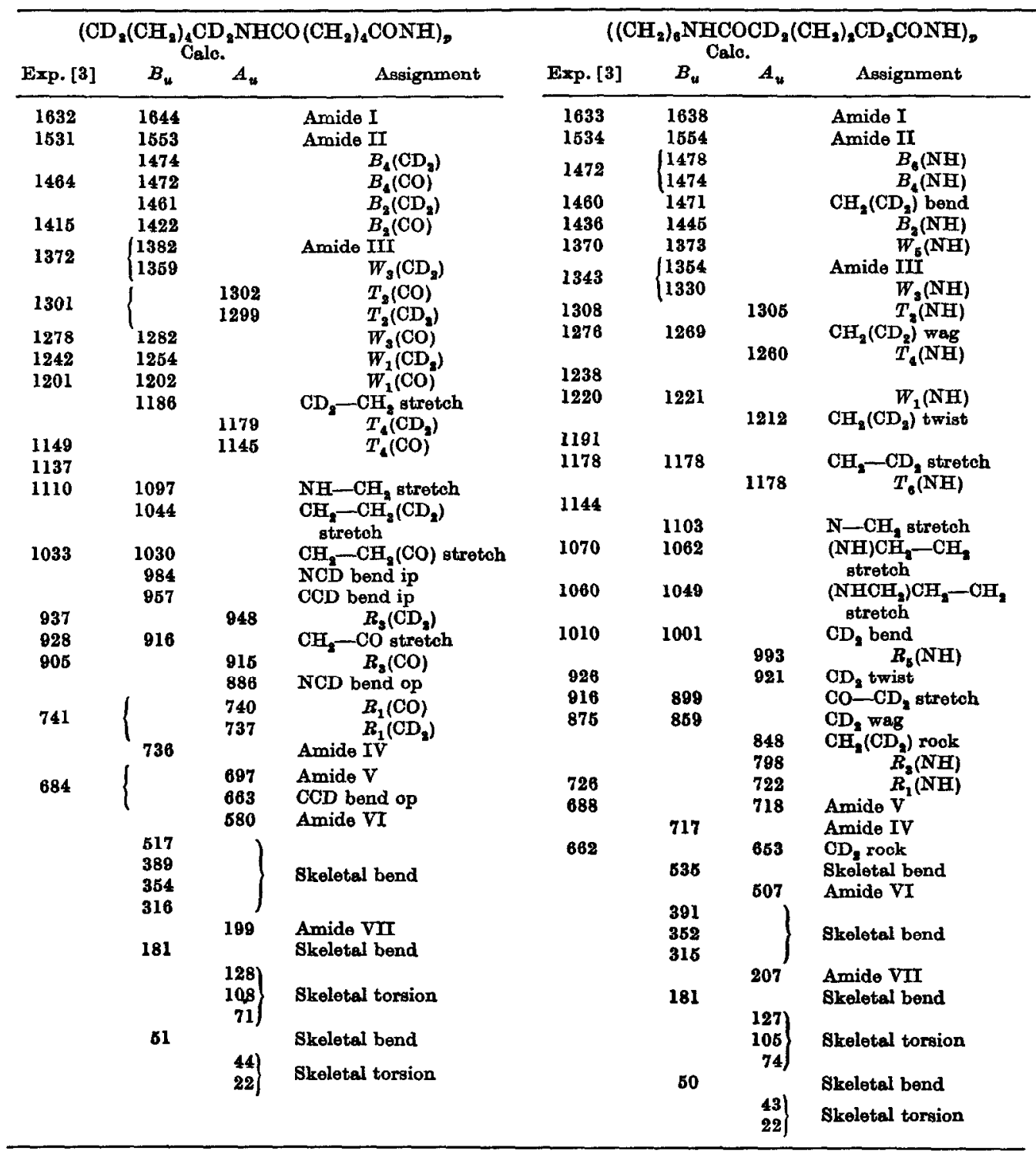




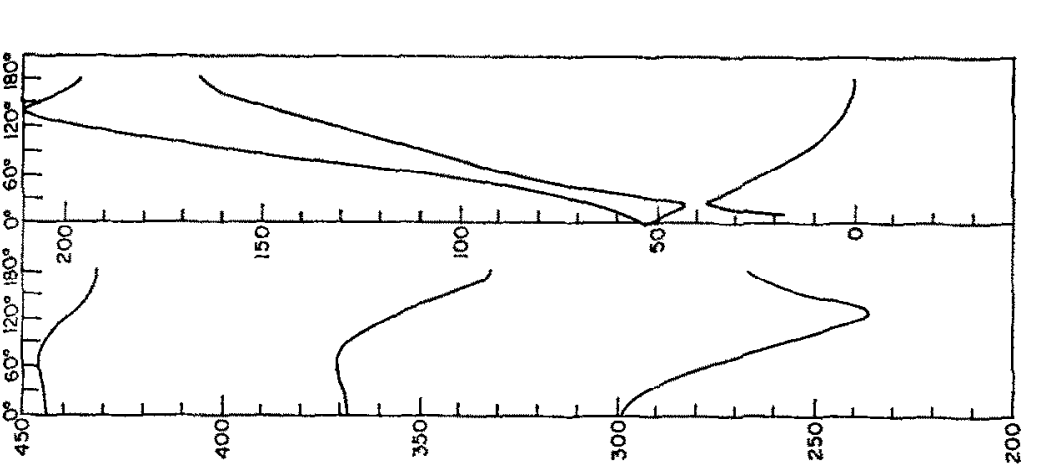

$\mathscr{8}$

章

อ.

宸

4

苨

$\infty$

$\frac{5}{8}$

3

密范

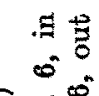

Ð

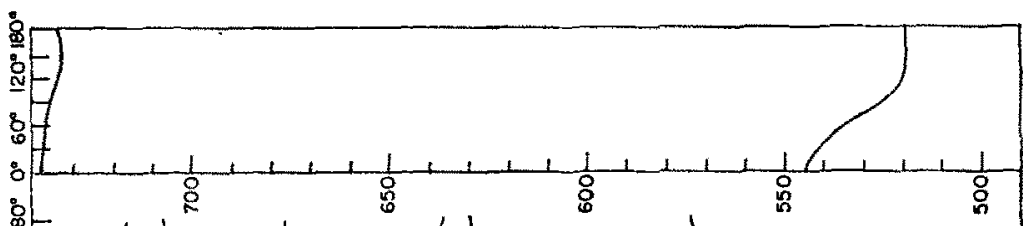

禹

영

国

오

호ㅇㅛㅛ

모

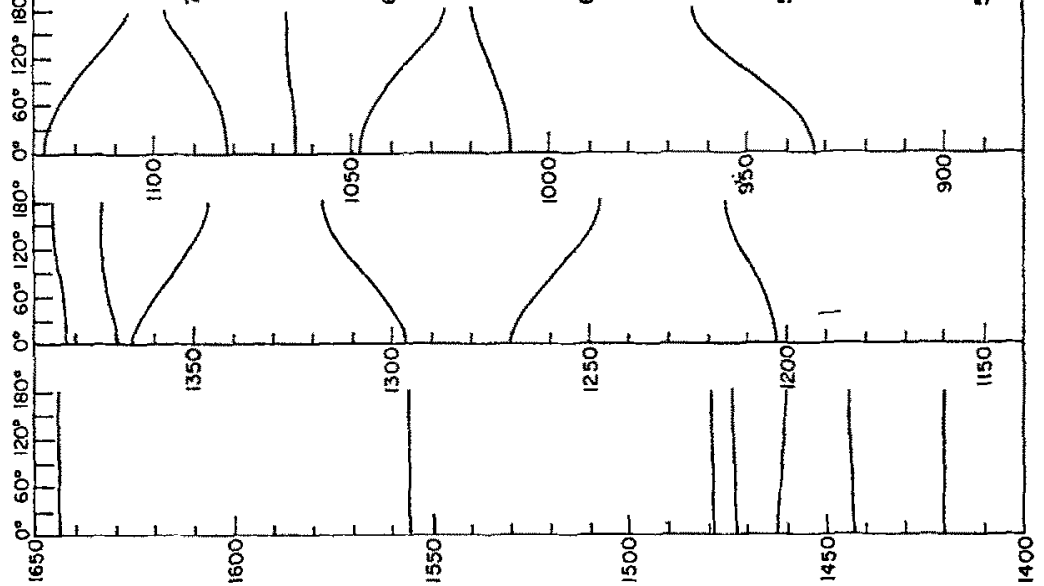

$\infty$

영

速

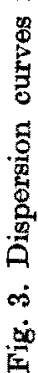




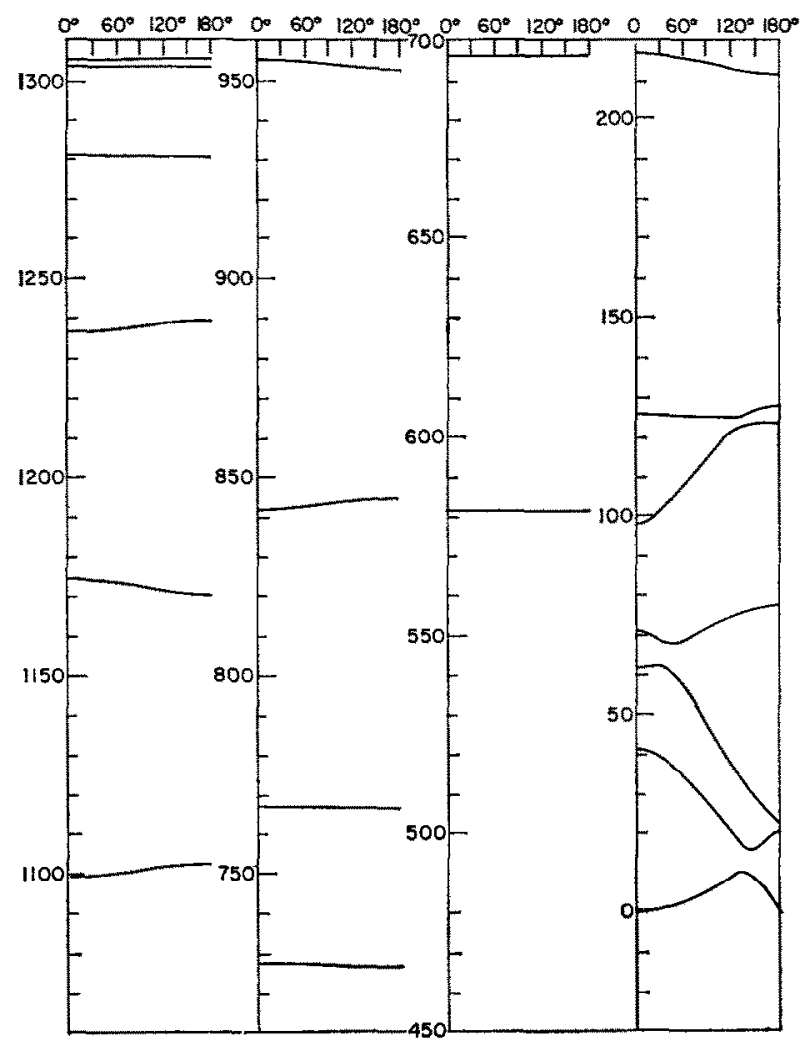

Fig. 3(b) 


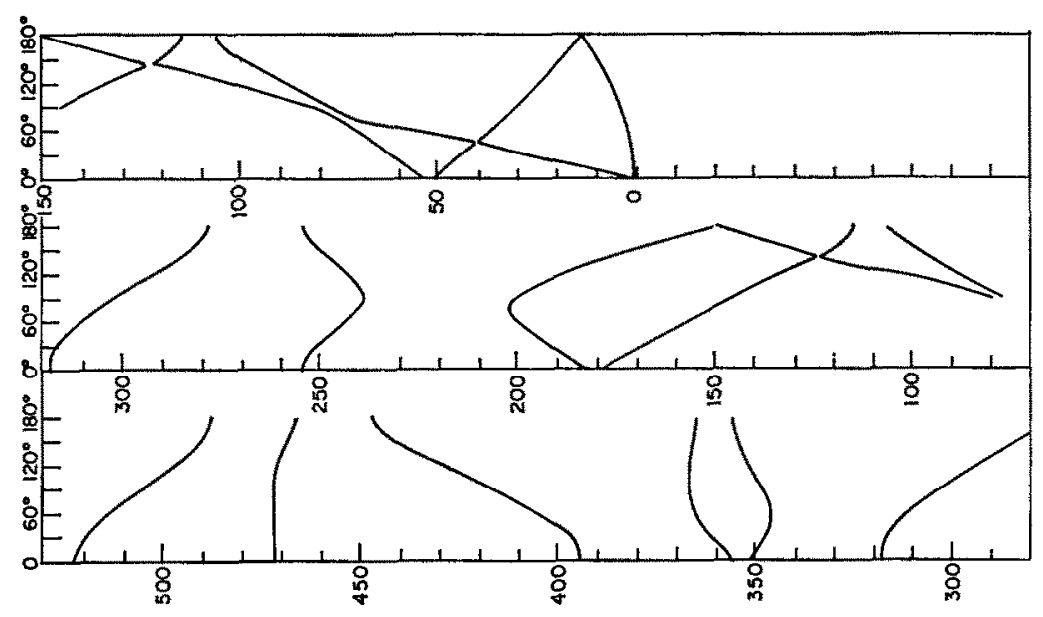

$\frac{0}{\infty}$

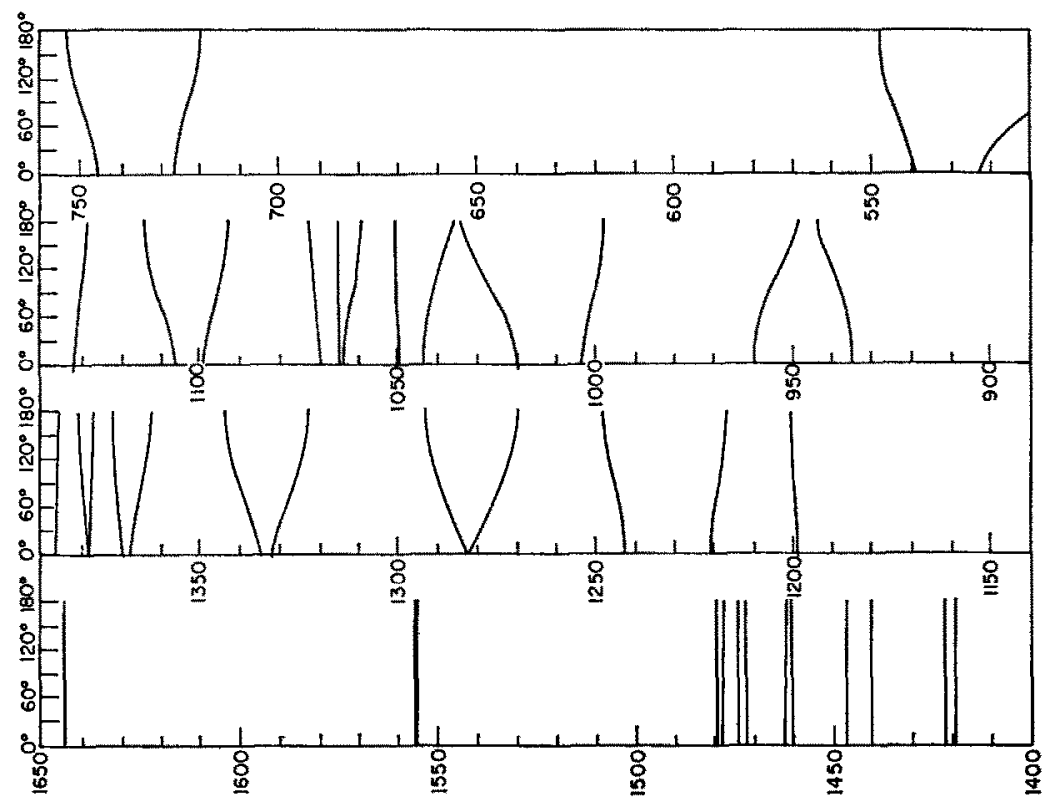




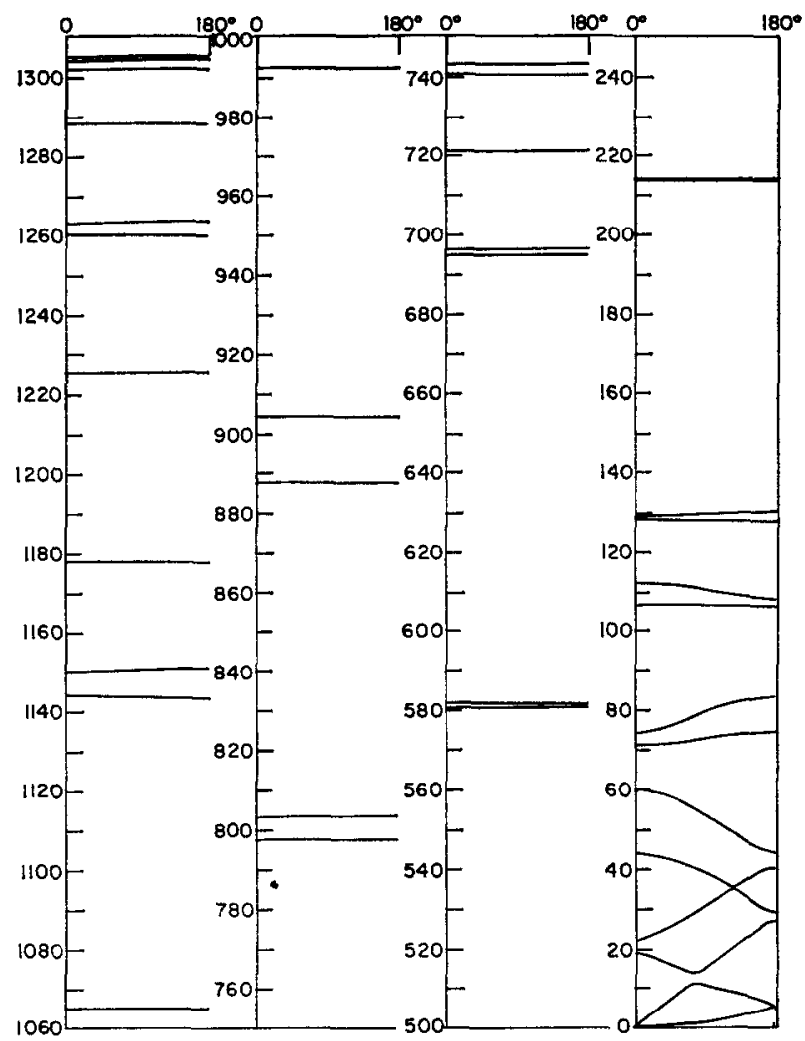

Fig. 3(d) 
1238, 1191 and $1144 \mathrm{~cm}^{-1}$ observed bands, no close calculated counterparts can be found, and to assign them $20-30 \mathrm{~cm}^{-1}$ errors would have to be admitted. The situation that introducing $\mathrm{CD}_{\mathbf{2}}$ groups worsens the agreement between calculated and experimental frequencies is known, e.g. from n-paraffins. In our case, the selective worsening after deuteration on the carbonyl side may indicate that further improvement of the force field on the carbonyl side may be possible provided some new data (e.g. from diamides) are available. This indication is also supported by the previously noted greater deviation in some $\mathrm{CH}_{2}(\mathrm{CO})$ wagging frequencies in diamides and in the $\mathrm{CH}_{2}(\mathrm{CO})$ bending frequency in the $\gamma$ form of nylon 6 .

\section{Dispersion curves of nylon 6 and nylon 66}

Dispersion curves of the $\alpha$ forms of nylon 6 and nylon 66 were calculated and are presented in Fig. 3. Above $700 \mathrm{~cm}^{-1}$ no extrema are observed in these curves, and most of them follow the simple $a+b \cos \phi$ function at least approximately. In the low frequency region the curves appear complicated at first sight. But their course may be easily understood if in first approximation we replace the $\mathrm{CO}$ and $\mathrm{NH}$ groups by $\mathrm{CH}_{2}$ groups. Dispersion curves for polyethylene, with phase difference multiplied by 7 (in nylon 6) or 14 (in nylon 66), then result. The similarity to these curves is striking, and the deviations near $\phi=0^{\circ}$ and $\phi=180^{\circ}$ and where two branches cross should be assigned to the change from the $\mathrm{CH}_{2}-\mathrm{CH}_{2}$ to the $\mathrm{CO}-\mathrm{NH}$ group.

\section{Conclustons}

Normal coordinate analyses of about 15 molecules containing the amide group were performed. Most features of their infrared spectra were explained, and an almost complete assignment of their infrared bands was established. The differences between calculated and experimental frequencies generally lie within $10 \mathrm{~cm}^{-1}$. Some greater differences occurred especially in the $C O$ vicinal $C$ deuterated nylon 66 , and also in some frequencies involving motion of the $\mathrm{COCH}_{2}$ group in other molecules. This may indicate the possibility of further improvement of the force field on the carbonyl side provided some new experimental data are available. The polarized infrared and Raman spectra of a more complete set of diamides would be most suited for this purpose.

Acknowledgment-This research was supported by a grant from the National Science Foundation. 